\title{
SOVEREIGN DEBT
}

Jonathan Eaton

Raquel Fernandez

Working Paper No. 5131

\section{NATIONAL BUREAU OF ECONOMIC RESEARCH 1050 Massachusetts Avenue \\ Cambridge, MA 02138 \\ May 1995}

Prepared for the Handbook of International Economics, edited by Gene M. Grossman and Kenneth S. Rogoff. We thank Andrew G. Atkeson and Torsten Persson for their comments. This paper is part of NBER's research programs in International Finance and Macroeconomics and International Trade and Investment. Any opinions expressed are those of the authors and not those of the National Bureau of Economic Research.

(C) 1995 by Jonathan Eaton and Raquel Fernandez. All rights reserved. Short sections of text, not to exceed two paragraphs, may be quoted without explicit permission provided that full credit, including (O) notice, is given to the source. 
NBER Working Paper \#5131

May 1995

\title{
SOVEREIGN DEBT
}

\begin{abstract}
We review the literature on sovereign debt. We organize our survey around three central questions: (1) Why do sovereign debtors ever repay their debts? (2) What burdens, in the form of distortions and inefficiencies, does sovereign debt impose? and (3) How might debt be restructured to reduce these burdens? In grappling with the first question the literature has pointed to, and argued about, the roles of reputation, punishments, rewards and renegotiation. In addressing the second the literature has asked whether sovereign debtors tend to borrow too much or too little, and how debt can distort the domestic economy. Answers to the third question include measures by creditors, by debtors, and by public institutions to reduce debt burdens.
\end{abstract}

Jonathan Eaton

Department of Economics

Boston University

270 Bay State Road

Boston, MA 02215

and NBER
Raquel Fernandez Department of Economics Boston University 270 Bay State Road Boston, MA 02215 and NBER 
1. Introduction

As the 1980's experience with sovereign debt made clear, international lending differs greatly from domestic lending and even more so from the textbook representation of a perfectly competitive, full information, loan market in which debt contracts are always honored. As Carlos F. Diaz-Alejandro remarked at the onset of the period, "we're not in Kansas anymore." 1 Repudiation, renegotiation, and reputation, are all words that quickly reentered the international lexicon as theoretical work strove to keep up with unfolding events. Much interesting work was generated as a consequence and it would be hard for any chapter of reasonable length to do this area full justice. Instead, we focus on a few key questions and papers to organize thinking about the literature and the issues, rather than attempt to be allencompassing.

The focus of this chapter is on specific problems posed by sovereign debt, that is, debt incurred by governments, typically those of developing countries, to foreign investors seeking a competitive return. ${ }^{2}$ Most recently sovereign debt has taken the form primarily of loans from commercial banks, although in earlier periods governments raised funds abroad mainly through bonds issued in foreign capital markets. Whatever form it has taken, three broad facts have characterized sovereign debt: (1) Governments have at times been able to borrow substantial amounts. (2) Much of what they borrow they eventually repay. (3) Repayment is often complicated, involving delay, renegotiation, public intervention, and default. ${ }^{3}$ The literature we survey here is meant to provide an understanding of these facts.

We organize the literature around three central questions. The first, addressed in section 2 , is why countries ever choose to repay their debts. This question forced the literature to confront the strategic nature of sovereign lending and led to the development of relatively sophisticated models which identify

${ }^{1}$ Diaz-Alejandro (1984).

${ }^{2}$ We do not survey work on government debt to public institutions, on private borrowing in international capital markets, or on direct foreign investment, although much of the literature that we survey contains lessons for these phenomena as well.

${ }^{3}$ For example, a number of middle-income developing countries began to receive substantial net resource transfers from private creditors in the early 1970s. For the largest debtors, those classified by the World Bank as "severely indebted middle-income countries," such transfers constituted nearly 2 per cent of GNP at their peak in 1976. The direction of these transfers was reversed in 1983. For the remainder of the decade these countries made net resource transfers to their private creditors, which peaked in 1986 at over 2 per cent of GDP. Sovereign debt for this group constituted over 30 per cent of GDP at its maximum in 1986. (World Bank (1993).) 
various motives for repayment. These models yield different predictions about the quantity that will be lent and the behavior that will ensue. ${ }^{4}$ The second question, the topic of section 3 , is what can go wrong. The literature has identified problems that can emerge at various stages in the relationship between creditors and debtors which can generate inefficient outcomes. The focus is on inefficiencies that can arise both in the lending stage and in the debtor's subsequent investment and consumption behavior. The last question, the concern of section 4 , is what can be done to correct these problems. The literature here, both theoretical and empirical, examines the effects of debt overhang, the potential benefits of debt buybacks to creditors and debtors, the role of third parties, and the functioning of secondary markets more generally. We conclude in section 5 with a discussion of some insights the literature may provide for alternative forms of international finance.

\section{Repayment Incentives}

Why do sovereign debtors ever repay their debts? The search for an answer to this question has motivated much of the research in this field. Our understanding of the conditions necessary to support repayment (and therefore lending in the first place) has been much advanced as a consequence. To avoid some of the (often terminological) confusion that emerged, we focus on a few key issues rather than take a chronological approach to the literature.

To begin with, sovereign debt differs from private debt in two important respects. First, there is often little that a sovereign entity can use as collateral to guarantee the value of a loan. Second, the ability of a court to force a sovereign entity to comply with its wishes is extremely limited. An immediate implication is that the country's desire to avoid some sanction, if it fails to repay, or to obtain some reward if it repays, must be central.

The fact that debt repayment cannot be enforced automatically meant that the challenge, especially early in this literature, was not so much to produce a model consistent with some set of "stylized facts," but rather to explain the phenomenon of sovereign lending in the first place. In fact, much of the

${ }^{4}$ There is little empirical work on this question. Exceptions are Eichengreen and Portes (1986), Lindert and Morton (1988), and Ozler $(1991,1993)$, who examine how the debt repayment in the 1930s differed from that of the 1980s, and whether subsequent credit terms differed for countries that had defaulted. 
literature can be viewed as an attempt to clarify the role played by different benefits or penalties, for example, exclusion from future credit markets, inability to conduct trade, difficulties in borrowing in the domestic credit market, or a loss of output. The dichotomy between benefits and penalties is artificial, depending solely on what initial state is identified with the status quo. ${ }^{5}$ A critical difference, however, is between types of penalties is whether creditors possess the ability to commit to penalizing a debtor that is in default and, if so, whether penalization takes the form of a commitment to a given level of punishment or to a particular punitive instrument. Assumptions about the existence of this technology are very often made implicitly in this literature. Another feature critical to understanding the efficacy of sanctions is the debtor's environment, i.e., the alternatives open to a defaulting country. This issue attracted more attention.

This section starts out first by examining, in a variety of environments, the ability of a particular penalty--the exclusion from credit markets--to support repayment. We choose to focus on this sanction in particular both because of its prominence in the literature and because, unlike in simple penalty models, while commitment to this punishment is assumed, the value of the penalty (i.e. the disutility derived from it) is generally determined by the country's actions. The assumption that creditors have the ability to commit to a penalty is then dropped and the efficacy and consequences of various other proposed penalties is examined in the context of sovereign-debt renegotiation.

\subsection{Can Exclusion From Future Credit Markets Support Repayment?}

This question has motivated much of the literature within this field. Often, and perhaps unfortunately, it has been couched in terms of "reputation." That is, as asking whether a country will repay its debt in order to maintain a "good" reputation for repayment. While the desire to maintain a reputation can be interpreted as different from the desire to avoid a penalty or reap a reward, the two are often confused. The exclusion of a country from future lending is, of course, a penalty. Hence, one question is whether the sole penalty of exclusion from credit markets in the future is sufficient incentive

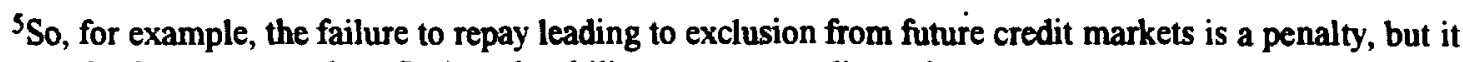
can also be recast as a benefit, i.e., the ability to access credit markets upon repayment.
} 
for a country to repay its debts. The answer, not surprisingly depends on the alternatives open to the country in a sense that will be made specific further on. We now review some of the major insights generated in this area.

An early model here is that of Eaton and Gersovitz (1981). In this model, the desire to maintain future access to credit markets provides an incentive to repay, although in general the first best amount of lending (i.e. the amount of lending that would be done in the absence of the relevant incentive compatibility constraints) is not sustainable. We now turn to a simple framework in which to review their arguments.

Consider a country that faces a gross world interest rate $r>1$, and has a discount factor $\beta<1 / r$.

The country seeks to maximize at time $t$ an intertemporal utility function given by $U_{t}=\sum_{i=t}^{\infty} \beta^{x} u\left(c_{t}\right)$.

For simplicity, suppose that this country's output $y_{t}$ is exogenous and deterministic and that there is no storage technology. Its debt evolves according to $D_{t+1}=\left(D_{t}-p_{t}\right) r$, where $p_{t}=y_{t}-c_{t}$ is the payment made by the country to its creditors at time $t$. Note that $p_{t}$ negative simply indicates a payment from the creditors to the country.

Were the country able to credibly promise to repay its debt, it would face a maximization problem given by:

$$
\operatorname{Max}_{c_{t}} U=\sum_{t=0}^{\infty} \beta^{r} u\left(c_{t}\right) \text { s.t. } \sum_{t=0}^{\infty} \frac{c_{t}}{r^{t}} \leq \sum_{t=0}^{\infty} \frac{y_{t}}{r^{t}}
$$

where the constraint in equation (2.1) is a simple feasibility constraint requiring that the present discounted value of consumption not exceed the present discounted value of output. Note that under financial autarky this constraint would imply $c_{t}=y_{t} \forall t$. The first order condition for the above maximization problem is:

$$
(r \beta)^{\prime} u^{\prime}\left(c_{t}\right)=\lambda \quad \forall \mathrm{t} .
$$

where $\lambda$ is the Lagrange multiplier associated with the feasibility constraint in equation (2.1). 
Let the country's utility function be given by $u\left(c_{t}\right)=\log \left(c_{t}\right)$. Furthermore, assume that $y_{t}$ can take on only two values: $y_{H}$ in odd periods and $y_{L}$ in even ones, with $y_{H}>y_{L} \geq 0$.

To solve for the country's optimal consumption path, note that, starting from a period in which the value of output is low, the present value of the country's future resources is given by:

$$
V_{0}=\frac{r\left[r y_{L}+y_{H}\right]}{r^{2}-1}
$$

Thus, were the country able to commit to debt repayment, its optimal consumption path would satisfy,

$$
c_{t}^{*}=[r \beta]^{t}(1-\beta) V_{0}
$$

where * denotes the optimal choice of the variable.

Let us now drop the assumption that the country can commit to the repayment of its debt. Then in addition to the feasibility constraint, the maximization problem of (2.1) must also respect an incentive compatibility constraint of the form:

$$
\widetilde{W}_{t}=\sum_{\tau=t}^{\infty} \beta u\left(\widetilde{c}_{\tau}\right) \geq V_{t}=\sum_{\tau=t}^{\infty} \beta u\left(y_{\tau}\right) \quad \forall \mathrm{t}
$$

where $\sim$ denotes the value of the variable given that the country is following some specified repayment path. Equation (2.5) expresses the requirement that the country be at least as well off, at each and every moment in time, repaying its debt according to some given repayment path, as it would be by defaulting on repayment and consuming its autarkic output thereafter. Note that, among other things, this restriction implies that there can be no time $s$ such that for all $t>s$ the country is making non-negative payments.

It is easy to see that the consumption path implied by the solution to equation (2.4) is strictly decreasing over time (since $\beta r<1$ ) and that, in the limit as $t \rightarrow \infty, c^{*} \rightarrow 0$. That is, under full commitment the country would borrow in order to increase its consumption at first and then slowly lower its consumption to zero, fully repaying its debt over time. An immediate consequence of dispensing with the commitment technology, therefore, is that it is no longer possible for the country's borrowing path to support its optimal consumption path since after some time $\tau$ this path would have the country consume an amount strictly smaller than $y_{L}$. This would violate the incentive compatibility constraint expressed in 
(2.5), since once the country's consumption drops below $y_{L}$, it can do strictly better by reneging on its debt and consuming its autarkic output thereafter. This is a very general message that emerges from the debt literature: the existence of incentive compatibility constraints in addition to feasibility implies that the first best allocation is rarely attainable.

Having established that the optimal consumption path cannot be supported in the absence of a commitment technology, it remains to be asked whether the threat of financial autarky is sufficient to support any borrowing at all. In order for this question to be answered affirmatively, there must exist a borrowing-repayment path such that (2.5) is always respected. To show how this can come about, we examine a stationary path in which the amount $\mathrm{x}$ is borrowed in low output periods and the amount $\mathrm{rx}$ is repaid in high output periods and solve for the optimal consumption path under this rule.

A necessary condition for repayment is first that there exist the desire to smooth consumption in the manner specified above. From (2.2), the condition for this is $r \beta y_{H}>y_{L}$. Note, however, that this condition is not sufficient since it does not address the country's temptation to renege on its repayment in a high output period. In order to find a necessary and sufficient condition we rewrite the constraint in (2.5) more explicitly for the specific utility function and endowment paths assumed. Since the problem is stationary, we can write the constraint as:

$$
\log \left(y_{H}-r x\right)+\beta \log \left(y_{L}+x\right)>\log \left(y_{H}\right)+\beta \log \left(y_{L}\right)
$$

Since the two sides of the inequality are equal at $x=0$, a necessary and sufficient condition for a stationary path with positive lending to be sustained is that the derivative of the left hand side is positive when evaluated at $x=0$. Taking the appropriate derivative yields:

$$
\beta y_{H}>r y L_{L}
$$

as the required condition. Note that this condition is indeed more restrictive than that needed to ensure the desirability of consumption smoothing. The reason for this is straightforward. Whereas the desire to smooth consumption requires the country to be willing to forego $\mathrm{rx}$ next period in exchange for $\mathrm{x}$ this period, the incentive-compatibility constraint requires the country to be willing to forego $\mathrm{rx}$ this period in exchange for merely $x$ next period. It is easy to show that if (2.7) is satisfied, the country's optimal stationary borrowing is given by $\mathrm{x}=\left[\beta y_{H}-r y_{L}\right] /[r(1+\beta)]$. 
Other papers that examine the same motivation to repay include Atkeson (1991), Cole, Dow, and English (1995), Grossman and van Huyck (1989), and Manuelli (1986). An important assumption made throughout, however, either explicitly or implicitly, is that the country could not enter into another financial agreement (e.g., an investment or insurance contract) after it reneged on its debt. We now turn to an examination of the consequences of relaxing this assumption.

\subsection{The Debtor's Environment}

Several later papers in the literature changed the focus of the question from the nature of the mechanism that might support sovereign lending to the type of environment that might destroy it. An influential paper in this vein is Bulow and Rogoff (1989b)

In "LDC Debt: Is to Forgive to Forget," Bulow and Rogoff (1989b) argue that if a country is able to enter into a particular type of contract irrespective of its behavior regarding its debt contract, then the sole threat of exclusion from future borrowing is unable to sustain positive lending. Before reviewing their argument in a general framework with uncertainty, it is instructive to show how allowing the economy described in the previous section (i.e., a pure endowment economy) to invest or open an account in which it earns the capital market's rate of return destroys its ability to borrow.

Consider, therefore, a non-stochastic endowment economy with access to a storage technology (or independent bank account) whose proceeds are not seizable by creditors and which provides a rate of return equal to that demanded by creditors, i.e., r. Assume that the value of all future output discounted to any time $t$ is bounded. Then there necessarily must exist an upper bound, say $M>0$, which creditors will not allow the country's debt to exceed. We will show that as long as $M$ is strictly positive, the country's ability to invest or to make payments and withdrawals that eam it the market rate of return will lead it to renege on its debt. This ability consequently destroys the country's access to funds.

Let $s$ be the period in which the country's debt equals $M$ and let variables with $a \sim$ indicate the values that those variables take when the country follows a given repayment path. ${ }^{6}$ Furthermore, let $A_{t}$ be

${ }^{6}$ For simplicity of exposition we assume that the upper bound is attained; it is easy to see how the argument should be modified otherwise. 
the country's investment in period $t$ in the account that earns the (gross) market rate of return $r$, and let $G_{t}$ be its return in period $t$. Note that $A_{t}$ is the total amount held by the country in its account during period t. Since this account is self-financed, $A_{t}$ must be non-negative. We next show that for any path of $\tilde{A}_{t}, \tilde{p}_{t}$ with positive debt, there always exists a deviation such that the country reneges on its debt and is made strictly better off.

Consider the following deviation from the strategy of following the repayment path as of period s. Let the country take the payment that it was called upon to make that period, $\tilde{p}_{s}$, and instead invest it in the alternative account, together with any other additional investment it would have made that period, i.e. $\tilde{A}_{s}$. Note that since $\tilde{D}_{\mathrm{s}}=\mathrm{M}$ and $\tilde{D}_{\mathrm{s}+1}=\mathrm{r}\left(\tilde{D}_{\mathrm{s}}-\tilde{p}_{\mathrm{s}}\right) \leq \mathrm{M}$, it follows that $\tilde{p}_{s} \geq \mathrm{rM} /(\mathrm{r}-1)>0$. That is, the country is investing a strictly positive amount in its account. The following period the country obtains $\mathrm{G}_{\mathrm{S}+1}=\mathrm{r}\left(\tilde{A}_{s}+\tilde{p}_{s}\right)=\tilde{G_{s+1}}+\tilde{r} \tilde{p}_{s}$ To reduce notation denote $\tilde{p}_{s}$ by $\dot{g}_{\mathrm{S}+1}$. The country continues with the modification of its original strategy by making an additional investment of $\tilde{p}_{s+1}$ into the account, so that $\mathrm{A}_{\mathrm{s}+1}=\tilde{A}_{s+1}+\mathrm{g}_{\mathrm{S}+1}+\tilde{p}_{s+1}$. Note that $\mathrm{A}_{\mathrm{S}+1}$ is strictly positive since $\tilde{A}_{s+1}$ is non-negative and $\mathrm{g}_{\mathrm{S}+1}+\tilde{p}_{s+1}=$ $\mathrm{rM}-\left(\tilde{D}_{\mathrm{s}+1}-\tilde{p}_{s+1}\right) \geq \mathrm{rM}-(\mathrm{M} / \mathrm{r})>0$. Thus, $\tilde{p}_{s+1}$ can be negative (in which case the country is making itself a payment from its account). It is easy to show that by continuing to invest $\tilde{A}_{t}+\mathrm{gt}_{\mathrm{t}}+\tilde{p}_{t}$ in every period following $s$, the country's consumption path is unchanged from what it was under the $\sim$ plan and its savings $\tau$ periods after $s$ is no smaller than $\tilde{A_{s+\tau}}+\mathrm{Mr}^{\tau}-(\mathrm{M} / \mathrm{r})$, i.e. it exceeds the original savings by a strictly positive amount. It follows that in any period after $s$, the country can increase its consumption above the amount called for by its repayment program by using some of these additional savings (but leaving itself with at least an additional amount $\mathrm{M} / \mathrm{r}$ in its account). Thus, this strategy leaves the country strictly better off than following its repayment plan. Consequently, the only $M$ that can be maintained as an upper bound in equilibrium is $M=0$, i.e., there can be no positive lending.

The intuition behind the argument given above is straightforward. Once the value (appropriately discounted) of the country's debt is sufficiently high, it has an incentive to default with probability one if it can obtain the market rate of return by opening an account or making an investment. This must be true 
once the value of the debt has reached its maximum since the amount paid out by the country from that time period on to each and every other future time period has a positive present discounted value. ${ }^{7}$ This implies that as of time period $\mathrm{s}$, and following the allocation rule $\sim$, there is no period in which the bank is lending the country an amount that the country could not have self-financed solely by accumulating its payments as of period $s$ in an interest bearing account. This alternative is naturally preferable since in addition it allows the country to default on the outstanding debt. Of course, the country's ability to pursue this strategy only makes it worse off, since it implies that no loans will be made in the first place.

Rosenthal (1991) shows that the argument given above can be generalized to the case of a concave storage technology or investment function (e.g., a production function in which the rate of return is a decreasing function of the capital invested) where the motivation to borrow is that, at least initially, the rate of return on the country's investment project exceeds that of the world capital market. Although the argument is more complex, the basic intuition underlying this result is the similar to that above. That is, once the value of the country's future net payments is sufficiently high the country is better off making use solely of its own technology and defaulting on its debt

We now turn to a more general version of the first argument as made by Bulow and Rogoff, which allows for uncertainty but which, as a result, also requires stronger assumptions.

We consider an economy whose production function is given by $\mathrm{Y}_{\mathrm{t}}=\mathrm{f}\left(\bar{I}_{t-1}, \bar{\theta}_{t}\right)$ where $\bar{I}_{t-1} \equiv\left(\mathrm{I}_{\mathrm{t}}\right.$ $\left.1, I_{t-2}, \ldots\right)$ and $I_{t}$ is investment in period $t$ and $\bar{\theta}_{t} \equiv\left(\theta_{t}, \theta_{t-1}, \ldots\right)$. The $\theta_{i}$ 's are assumed to be exogenous and serially independent shocks. Both $\bar{I}_{\imath}$ and $\bar{\theta}_{\ell}$ are assumed to be observable and verifiable. At the beginning of each period the shock is realized and observed and then the country makes its allocation decisions for that period.

Consider a debt contract that specifies, for every verifiable state of nature $\bar{\theta}_{t}$ and for every time period $t$, a payment $p_{t}\left(\bar{\theta}_{t}\right)$. Note that, as before, $p_{t}$ may be positive or negative depending on whether a payment from the country to its creditors or its reverse is indicated. The contract can be implicit or explicit (in any case, as before, creditors are assumed to have the power to commit to making any positive

${ }^{7}$ If it didn't, then the value of the outstanding debt under the plan $\sim$ would have, as of that period, exceeded $M$. 
payments called upon by the contract). Lastly, as before, any default by the country excludes it from all future debt contracts; there is no other penalty.

Before proceeding with the argument we introduce some useful definitions. Define,

$$
\widetilde{W}_{t}\left(\bar{\theta}_{t}\right)=E_{t} \sum_{s=t}^{\infty} \tilde{y}_{s} / r^{s-t}
$$

where the $\sim$ denotes a particular allocation path and $\tilde{y}_{s}=\tilde{Y}_{s}-\tilde{I}_{s} \geq 0$ and $\tilde{W}_{1}<\infty \forall \mathrm{t}$. Equation (2.8), therefore, gives the expected market value of a claim to the country's entire future income as of period $t$ (given that the country follows the allocation path $\sim$ ). Furthermore, define

$$
\tilde{D}_{t}\left(\bar{\theta}_{t}\right)=E_{t} \sum_{s=1}^{\infty} \rho_{s} / r^{s-t}
$$

as the country's expected present discounted value of its future repayments (again following the allocation path $\sim$ ). Clearly, in order for the debt to be payable according to this path, it must be that $D_{t}\left(\bar{\theta}_{t}\right) \leq W_{t}\left(\bar{\theta}_{t}\right)$ for all $t$ and all $\bar{\theta}_{t}$. That is, the value of the debt must not exceed the value to a claim to the country's entire future output stream. Lastly we define $k$ as the smallest $k$ ' such that for all $t$,

$$
\tilde{D}_{t}\left(\bar{\theta}_{t}\right) \leq k \tilde{W}_{t}\left(\bar{\theta}_{t}\right) \quad \forall \bar{\theta}_{\mathrm{t}}
$$

Note that,

and that

$$
\mathrm{E}_{\mathrm{t}} \tilde{W}_{\mathrm{t}+1}=\mathrm{r}\left(\tilde{W}_{\mathrm{t}}-\tilde{y}_{\mathrm{t}}\right)
$$

$$
\mathrm{E}_{\mathrm{t}} \tilde{D}_{\mathrm{t}+1}=\mathrm{r}\left(\tilde{D}_{\mathrm{t}}-\tilde{p}_{\mathrm{t}}\right)
$$

where $\bar{\theta}_{t}$ is suppressed (here and henceforth) unless required for clarity.

In addition to debt contracts, the country is also able to enter into cash-in-advance type contracts (for simplicity assumed to be of one period). In such a contract the country, by paying an amount $A_{t}$ at the end of period $t$ (i.e., after $\theta_{t}$ has been observed), receives in exchange $G\left(\bar{\theta}_{t+1}\right)$ in period $t+1$. This contract must satisfy two requirements:

(i) $\mathrm{E}_{\mathrm{t}}\left[\mathrm{G}_{\mathrm{t}+\mathrm{l}}\left(\bar{\theta}_{\mathrm{t}+\mathrm{l}}\right)\right]=\mathrm{rA}$ and 
(ii) $\mathrm{G}_{\mathrm{t}+1}\left(\bar{\theta}_{t+1}\right) \geq 0 \forall \bar{\theta}_{t+1}$

The first condition states that the country should obtain in expected value terms the market rate of return the following period., where $r$ continues to be the (gross) world risk-free interest rate. If we assume that the country is small in international capital markets, i.e., unable to affect this rate, then this condition would follow from the existence of a perfectly competitive "cash-in-advance market" with riskneutral lenders. The second condition indicates that a one-period contract at time $t$ cannot be designed to require a strictly positive payment from the country at time $t+1$ (since the country would have no incentive to repay it). Note that the assumption of competitive markets implies that the country can write the cashin-advance contract in any way it wishes as long as it respects the two requirements above. That is, we are assuming in particular that this contract can be made contingent on the same variables as the debt contract.

We now show that if the country can enter into the type of contract specified above, then this possibility destroys all equilibria with positive debt since there will always exist a state in which the country will be able to do better by reneging on its debt contract.

Consider a time period s and a history of shocks $\bar{\theta}_{s}$ such that $D_{s} \geq k\left(W_{s}-y_{s}\right)>0$ (note that by equation 2.10 this state must exist). Without loss of generality in what follows we normalize all cash-inadvance contracts made under the repayment plan $\sim$ to zero in this and in every succeeding period. We now show that the country can as of this period make itself strictly better off by reneging on all future payments and following the strategy described below. This strategy will allow the country to maintain the same investment path as under the debt contract and strictly increase its consumption in some time periods without decreasing it in any other period.

Thus, instead of making its called upon payment of $\tilde{p}_{a}$ that period, let the country invest the amount $A_{s}=\tilde{p}_{s}+k\left(\tilde{W}_{s}-\tilde{y}_{s}\right)-\tilde{D}_{s} \leq \tilde{p}_{s}$. Note that $\tilde{p}_{s} \geq 0$ since otherwise, by (2.11) and (2.12), we would have $\tilde{D}_{t+1}>k \tilde{W}_{t+1}$ which is ruled out by definition of $k$. The same reasoning yields $\mathrm{A}_{\mathrm{s}} \geq 0$.

In every subsequent period $\mathrm{t}>\mathrm{s}$, let the country invest $A_{t}=G_{t}+\tilde{p}_{t}-\tilde{k y_{t}}$ in return for $\mathrm{G}_{\mathrm{t}+1}\left(\bar{\theta}_{t+1}\right)=\mathrm{k} \tilde{W}_{\mathrm{t}+1}\left(\bar{\theta}_{t+1}\right)-\tilde{D}_{\mathrm{t}+1}\left(\bar{\theta}_{t+1}\right) \geq 0$. Note that this cash-in-advance contract fulfills both 
requirements stipulated previously since, by (2.11) and (2.12), $\mathrm{E}_{\mathrm{t}} \mathrm{G}_{\mathrm{t}+1}\left(\bar{\theta}_{t+1}\right)=\mathrm{kE} \tilde{W}_{\mathrm{t}+1}\left(\bar{\theta}_{t+1}\right)$ $\mathrm{E}_{\mathrm{t}} \tilde{D}_{\mathrm{t}+1}\left(\bar{\theta}_{t+1}\right)=\mathrm{r}\left[\tilde{W}_{\mathrm{t}}\left(\bar{\theta}_{\mathrm{t}}\right)-\tilde{y}_{\mathrm{t}}\left(\tilde{D}_{\mathrm{t}}\left(\bar{\theta}_{t}\right)-\tilde{p}_{\mathrm{t}}\right)\right]=\mathrm{r}\left[\mathrm{G}_{\mathrm{t}}+\tilde{p}_{\mathrm{t}}-\tilde{y}_{\mathrm{t}}\right]=\mathrm{rA} A_{\mathrm{t}} \geq 0$. In any time period $\mathrm{t}$ in which $\tilde{p}_{\mathrm{t}}$ would take a negative value (i.e. the country would have received a further loan from the banks) the country is simply making this payment to itself from $G_{t}$. The accumulated funds are always sufficient for it to be able to do so since $A_{t}=G_{t}+\tilde{p}_{t}-k \tilde{y}_{t}=k\left(\tilde{W}_{t}-\tilde{y}_{t}\right)-\left(\tilde{D}_{t}-\tilde{p}_{t}\right)=\left[\mathrm{kE}_{t} \tilde{W}\left(\bar{\theta}_{t+1}\right)-\right.$ $\left.\mathrm{E}_{\mathrm{t}} \tilde{D}_{\mathrm{t}+1}\left(\bar{\theta}_{t+1}\right)\right] / \mathrm{r} \geq 0$

Note that by following the strategy outlined above the country is in each period making zero debt repayments and instead is making an additional cash-in-advance contract of $\tilde{p}_{\mathrm{t}}-\mathrm{k} \tilde{y}_{\mathrm{t}} \leq \tilde{p}_{\mathrm{t}}$, i.e., no greater than the payment that it would have made to its creditors in that period. This implies that the country can increase its consumption by the amount $\tilde{k}_{\mathbf{t}} \geq 0$ in each period. Furthermore, note that in at least one of the periods following $s$ the expected value of this consumption increase must be strictly positive.

Otherwise, $\tilde{y}_{\mathrm{t}}$ would equal zero in all time periods after $\mathrm{s}$, which would imply that no payments were expected as of period s. But that would require that the value of the debt at time s be zero or negative, contradicting our initial assumption. Thus, the ability of a country to enter into the above type of cash-inadvance contracts makes it impossible for debt contracts to be supported solely by the threat of exclusion from borrowing.

Summing up, the point of the Bulow and Rogoff argument is that if cash-in-advance contracts, fully indexed to the same states of nature as the debt contract, are available to a debtor that reneges on its debts, then the exclusion from future debt contracts is insufficient motivation for a country to repay its debt.

Does this imply that one must look elsewhere than exclusion from future credit markets to explain sovereign lending? There are several assumptions in the model above that are unlikely to correspond fully with reality. First, it may be costly for a country to obtain cash-in-advance contracts, or the rate of return on these may be smaller than the return required by the country's creditors. While either possibility may permit positive lending to be sustained in equilibrium, the maximum amount of debt that 
could be supported by these costs would be precisely the amount that would make the country indifferent between switching to the cash-in-advance contract strategy and staying with its debt arrangement.

Alternatively, the creditor-debtor relationship may be special in that not all states of nature nor all actions taken by the country may be observable or verifiable outside it. Or, they may be observable and verifiable only at a large cost to outsiders who are less likely to have the expertise and on-going relationship with the country as a large commercial bank. This factor likewise would make it costly to switch to a cash-in-advance contract. How much debt these costs could support is an empirical question that needs to be addressed.

Second, the argument assumes that the insuring party can itself commit not to renege on its commitment to pay the amount stipulated by the contract. That is, while the initial creditor has a problem getting the initial debtor (i.e. the country) to repay, a debtor in default is assumed not to have this problem with its own debtors. This assumption may need justification. While it is relatively easy to believe that reputational considerations (e.g., their business with other clients) may usually be a sufficient incentive to impede the insuring party from reneging on its contractual commitments, these same considerations may not apply toward clients that are themselves in bad standing. Alternatively, these transactions may themselves be ruled out if the creditors possess the authority and means to seize any payments made to the reneging debtor.

In light of the above comments, Kletzer and Wright (1990) model a situation in which two agents, one risk-neutral creditor and the other risk-averse with a fluctuating endowment, have no external mechanism to enforce contracts with each other, i.e., no party has the ability automatically to enforce contracts in a unilateral fashion. Nevertheless, there exist subgame perfect equilibria in which the riskneutral agent provides some insurance to the risk-averse agent. If the two agents have equal discount factors then, as that discount factor approaches one, full insurance of the risk-averse agent is attained. If the risk-averse agent has a lower discount factor, however, then typically only partial insurance is achievable.

\subsection{Reputational Considerations}


Does the existence of cash-in-advance contracts rule out other mechanisms in which "reputation" plays a role? The answer is a qualified no and it is here that the terminology becomes confusing. If the question is whether it is possible for the exclusion from debt contracts to be a sufficient penalty to induce repayment, then one way to read the Bulow and Rogoff paper is that it provides a set of sufficient conditions for this punishment to be unable to support positive lending. If, on the other hand, the question is understood to mean will the country ever repay its debts in order to gain a reputation for doing so, then the question of "reputation" should be divorced from the cost of being excluded from capital markets (although this additional cost will only make the country more willing to gain this "reputation"). We now turn to a few examples that develop the reputational argument further.

Consider the possibility that a country's default on its debt obligation triggers an adverse reaction in some other relationship (or game) in which the country is involved. Why might this adverse reaction occur? One possibility is that it is part of a trigger strategy in a supergame. In such a scenario the country would be involved in an infinitely repeated game with either the same or with another party. The equilibrium of the one-shot version of that game should yield both parties a lower payoff than "cooperation", the term we will give to a particular pair of one-shot strategies that are not sustainable as equilibrium strategies in a finite horizon or one-shot game. The cooperative outcome, however, would be sustainable when the game is infinitely repeated, supported, for example, by the "grim" threat of forever playing the one-shot equilibrium strategies should one of the players ever defect from its cooperative strategy. (Of course, one may also construct strategies that are "renegotiation proof" to support this outcome by penalizing players that defect through the temporary play of the one-shot strategies). In addition, however, the strategies would specify that should the country at any moment default on its debt obligations (i.e., its other relationship), then this would also trigger the grim one-shot equilibrium strategies forever thereafter. As long as the benefits from maintaining this cooperative relationship outweighed the gains from defaulting on its debt, the country should be willing to repay its debts in order to maintain a reputation for repayment. Note, however, that it is the cost of the benefits foregone in the other relationship that make this behavior feasible. 
The mechanism specified above allows positive lending to be sustained but it also has some unappealing properties. In particular, while feasible, it is not compelling that the strategies in the second game depend on the actions of the debtor in the debt game. More appealing would be the possibility that some information would be revealed were the country to default. It is difficult to think of natural relationships in which this would be the case, however. It would require the existence of some characteristic which is private information that would affect both a country's willingness to pay and the action that another player would want to take in some other game.

Cole and Kehoe (1992) provide an example of the above situation in a finite horizon game with two types of government: One is the usual type with the kind of utility function that we have previously specified and the other, called "honest", by assumption incurs a large disutility cost from defaulting on any contract. The government, aside from its debt contract, also enters every period into a contract with a union which it promises to pay at the end of every period after that period's work is performed. In this case, were the type of government common knowledge then the sole subgame perfect equilibrium in the game between workers and the regular government must be the one-shot equilibrium of zero debt and no union contract, since in the last period of the game the government will renege on its payment to the union, thus unraveling all possibility of cooperation in any other period. If these preferences are private information, however, then the regular type government can attempt to gain a reputation for honesty, a la Kreps-Wilson (1982) and Milgrom-Roberts (1982), by repaying for some period of time. In such an equilibrium, for a long enough time horizon, even a small probability that the government is honest will allow some positive lending. How satisfactory it is to assume that this type of government (the "honest" type) exists is less clear.

The Kletzer and Wright (1990) paper previously discussed can also be read as an example in which reputation in the sense indicated above can sustain positive lending. Without automatic enforcement by either party, the only equilibrium in any finite relationship is autarky. If their interaction is indefinite, however, then there are subgame-perfect equilibria that sustain positive lending.

\subsection{Carrots and Sticks}


The earliest literature in this field studied the implications of various models in which creditors are able to penalize a debtor country by some amount $P$ if the latter does not repay its debt. This literature took as its starting point the notion that if $U_{p} \geq U_{d}$, where $U_{p}$ stands for the country's utility from repayment and $U_{d}$ stands for its utility from default, then the country would be willing to repay its debt

(ignoring solvency problems). .The implications of these models for how much debt the country repays are rather trivial; the interesting issues that arise instead are, for example, the importance of seniority clauses, possible inefficiencies in investment behavior, and the effects of various policies, all discussed in Section 3. Instead, we turn to an issue that arises less prominently when examining reputational considerations for repayment but that is central when one considers the possibility of costly penalties.

\subsection{Sovereign-Debt Renegotiations}

It would seem impossible to go wrong by saying, as above, that a country will repay its debt if its utility from doing so is greater than its utility from non-repayment. In the absence of a commitment technology on the part of the creditors (either to withholding the carrot or to applying the stick), the validity of this statement depends on the precise strategic environment. Once loans have been extended to the country, the relationship between creditor and debtor is one of bilateral monopoly. If penalizing the country is at all costly, then the implicit commitment assumed by much of the earlier literature is questionable. Formally, the question arises as to whether the strategies are subgame perfect, i.e., in the absence of commitment would the creditors really find it in their interest to apply the penalties were they called upon to do so. Furthermore, even if the strategies are subgame perfect, it is also questionable whether the strategy space is rich enough. For example, a creditor that must incur a cost $c$ in order to penalize a debtor by the amount $\mathrm{P}$ (with $c<\mathrm{P}$ ) may be unable to resort credibly to this punishment if the debtor is allowed to offer it a payment of P-c. Thus, whether the situation is modeled in such a way so as to allow the country the option of making this offer becomes critical.

A natural way to deal with the concerns raised above is to allow the relevant parties to bargain or to renegotiate their original debt contract. One of the first papers to allow for this possibility is Bulow and Rogoff (1989a). They use an infinite horizon, small country (unable to affect interest rates or the world 
prices of traded goods) model. The country's output is exogenously determined. The country obtains utility from consumption of both domestic and foreign goods and is assumed to be linear in both goods (this allows the bargaining game to be easily solved), with a rate of time preference given by $\delta$, i.e.

$$
U_{\mathbf{t}}=\sum_{\tau=t}^{\infty}\left(c_{\tau}^{\mathbf{d}}+c_{\tau}^{\mathbf{f}}\right) /(1+\delta)^{\mathbf{t}}
$$

In each period the country produces $\mathrm{Y}$ units of the domestic good. These can be consumed, stored or traded for foreign goods. Should the country store its goods, the next period the amount left over is reduced by the fraction $\gamma$. The authors assume that $q$, the relative price of the domestic good in terms of the foreign good, is greater than one. This ensures that the country would, everything else equal, prefer to trade its domestic goods for foreign ones.

The country can borrow abroad at the gross world interest rate of $r>1$. Creditors can, should the country fail to pay its debt (renegotiated or otherwise), seize a portion of its exports. The net benefit to them from doing so is assumed to be a fraction $\alpha$ of the country's exports. The country, should it attempt to trade when it has not repaid its (renegotiated or not) debt, obtains only a fraction $1-\beta$ of what it would have obtained were it in compliance with its creditors. It is assumed that $0<\alpha \leq \beta \leq 1$ and, to ensure that the country would wish to borrow, it is also assumed that $\delta>r$.

In order to determine the maximum quantity that creditors would be willing to lend a country under this scenario we proceed in three steps. First, note that if the country could commit to debt repayment, it would borrow and consume in the first period $Y /(r-1)$, and thereafter dedicate itself to repaying its debt.

Second, we drop the commitment assumption and examine the amount of debt that can be supported by the creditor's ability to impose a penalty on the debtor. The creditor's sole threat against the debtor is its ability to seize the country's goods should the latter attempt to trade without an agreement. Thus the country should be willing to pay the difference between what it would obtain were its trade unimpeded and what it would obtain should it trade without reaching an agreement, i.e., $\beta q Y /(r-1)$. Since the country always has the option of not trading and instead consuming its domestic output, however, 
lenders will only be able to obtain the minimum between the country's gains from unimpeded trade and what the country could obtain by not trading at all, i.e.

$$
\min [\beta,(q-1) / q] q Y /(r-1)
$$

The problem with this solution, however, is that it assumes that the creditor has all the bargaining power in the game, i.e. that it is up to the creditor to leave the debtor indifferent rather than, for example, vice-versa.

Third, therefore, we can allow, as do Bulow and Rogoff, for the country and its lenders to bargain a la Rubinstein (1982). In this bargaining game players take turns making offers to one another, the game ending when an offer is accepted. In order to avoid supergame equilibria, the authors assume that after some date $T$ in the future, the country's output falls to zero (they then take the limit as $T \rightarrow \infty$ ). By solving for the Rubinstein bargaining solution as of period $\mathrm{T}$ for a pie that is shrinking by the proportion $\gamma$ each period and then using backwards induction to find the outcome of the bargaining game as of the first period, it is possible to establish the outcome of the entire game. ${ }^{8}$

Since the details of the calculation are not particularly illuminating, we shall omit them here. Suffice it to note that, as in a regular Rubinstein bargaining game, the solution is efficient with agreement reached in the first period. The creditors obtain a share that depends inversely on the interest rate (since that makes the bank more impatient) and is proportional to $\delta$ (since.that makes the country more impatient). If, however, the share obtained by the country should yield it less than its implied share in (2.14), then the bargaining solution must be modified to yield the country its maximum "outside offer", i.e. the maximum of the shares $1-\beta$ and $1 / q$.

While bargaining is one way in which to deal with the problem of renegotiation, it is well known that bargaining models are quite sensitive to the exact specification of the bargaining game. Furthermore, too much emphasis may be given in these models to the ability of parties to talk-to make offers and counteroffers--rather than to other actions agents may be able to take. In light of this, Fernandez and Rosenthal (1990) construct a model that examines the bilateral monopoly question without introducing

\footnotetext{
${ }^{8}$ See Gale and Hellwig (1989) for an example of a renegotiation game with private information and multiple equilibria.
} 
bargaining in the form of an offer-counteroffer model. Instead the authors allow the parties to take actions which strategically determine the strength of the two parties. Their result lends support to models that have assumed that all the bargaining power lies with the banks since they obtain this same result in an explicitly strategic model.

The motivation for repayment in Fernandez and Rosenthal is of the "carrot" variety. The country's economy is specified as in a one-sector growth model. The country starts the game with a given amount of debt in place which grows according to a specified gross interest rate $r$. The game is one of alternating moves: in each period the creditor first decides how much, if any, of the debt it wishes to forgive, and then the debtor makes its consumption, investment and repayment decision for that period. The game ends (it can go on indefinitely) whenever the outstanding debt is repaid, whereupon the country automatically receives a "bonus" the following period. The "bonus" is not paid by the creditors. It can be interpreted as improved access to international capital markets, better ability to conduct trade, etc. The bonus function is assumed to be a continuous, increasing function of the capital stock that the country ends the game with, equaling zero if the country ends the game with zero capital.

A few definitions are helpful. Let

$$
v(K)=\operatorname{Max}_{0 \leq c \leq \boldsymbol{g}(K)}(u(c)+\beta v(g(K)-c))
$$

and

$$
\begin{aligned}
& w(K, D)=\operatorname{Max}_{c+p \leq g(K)}(u(c)+\beta w(g(K)-c-p,(1+r)(D-p) \\
& w(K, 0)=\operatorname{Max}_{c \leq \boldsymbol{g}(K)}(u(c)+\beta Z(g(K)-c)
\end{aligned}
$$

where $v(K)$ is the value to the debtor of maximizing utility under the assumption that it will never repay its debt and therefore never obtain the corresponding bonus and that it starts out with an initial capital stock of $\mathrm{K}$. Thus, (2.15) is simply the intertemporal optimization problem faced by an economy under financial autarky, and we refer to it as the country's stand alone program. Note that $K_{t+1}=g\left(K_{t}\right)-c_{t}-p_{t}$ The function $w(K, D)$, on the other hand, is the value to the debtor of pursuing an optimal plan (i.e. 
choosing consumption, investment, and repayments over time that are utility maximizing) for repaying its debt given that it starts out with a debt of $D$ and a capital stock $K$ and given that it assumes that in the future it will not obtain any debt forgiveness. Similarly, $w(K, 0)$ is the value to the debtor of having zero debt and obtaining the bonus $Z(g(K)-c)$ the following period given that it has a capital stock of $K$ in this period.

Lastly, define $\varphi$ as the non-negative value of debt forgiveness, $f$, such that $w(K, D-\varphi)=v(K)$, i.e., this is the value of debt forgiveness such that the debtor is indifferent between two options: pursuing an optimal repayment strategy given that it expects no future forgiveness, and following the optimal growth strategy with no repayment ever of the debt, and therefore no access to bonus. Note that if $w(K, D) \geq v(K)$, then $\varphi$ is defined to be equal to zero and that the evolution of the country's debt is given by $D_{t+1}=(l+r)\left(D_{t}-p_{t}-f_{t}\right)$.

The authors show that the unique subgame-perfect equilibrium has the creditor in each period setting $\mathrm{f}=\boldsymbol{\varphi}($ if $w(K, D) \geq v(K)$ than the creditor sets $\varphi=0)$. This amount of forgiveness ensures that the debtor is indifferent between repaying the remaining debt over time and following its stand alone program. Thus, in equilibrium the creditor forgives all the necessary debt in the first period and thereafter the debtor repays its debt optimally over time. Note that the equilibrium is efficient

The above result is rather surprising. It is natural to ask why the debtor cannot distort its investment path in such a way as to make the creditor worse off and extract more concessions. The important thing to note is that, while indeed the debtor can extract further reductions in its level of debt from the creditor by deviating from the w(.) plan, and in so doing make the creditor worse off, it has no incentive to do so given the creditor's strategy: Starting from any point at which $v(K)=w(K, D)$, any deviation on its part that results in $v\left(K^{\prime}\right)<w\left(K^{\prime}, D\right)$ will generate another forgiveness such that $v\left(K^{\prime}\right)=w\left(K^{\prime}, D-f\right)\left(w h e r e K^{\prime}=g(K)-c\right)$, but $v(K)=\max [u(c)+\beta v(g(K)-c)] \geq u(\tilde{c})+\beta v(g(K)-\tilde{c}) \forall 0 \leq \tilde{c} \leq \mathrm{g}(\mathrm{K})$. Therefore, the debtor is in fact not making itself better off by pursuing this deviation and consequently has no incentive to do so. It is more complicated to show that the equilibrium payoffs to this game are unique and thus that the creditors end up with all the "surplus" in the game. The authors demonstrate that any 
forgiveness which yields the debtor more utility than $V(K)$ can be decreased by some $\varepsilon>0$ without any adverse consequence to the creditor (indeed with net positive benefit), thus establishing payoff uniqueness.

Debt repayments and renegotiation have not shown the smoothness that the models discussed above predict. While it is probably possible to generate multiple periods of renegotiation and debt rescheduling by introducing uncertainty and shocks over time, there are two important ingredients left out of these models that undoubtedly play an important role in reality: (i) disagreement among creditors, and, interacting with the first, (ii) expectations about third party intervention. The next section discusses these and other factors that contributed to the problems encountered during the period of the debt crisis.

\section{What Can Go Wrong?}

A message of the previous section is that a sovereign country may lack the incentive to repay the amount of debt that it needs to finance its optimal investment and consumption program. We now turn to the distortions created by the inadequacy of these incentives. The literature suggests situations in which: (1) Sovereign countries borrow too much or too little. (2) Default leads to the suffering of sanctions that are a deadweight loss, such as a trade or credit embargo that leaves socially efficient intratemporal and intertemporal exchanges unexploited. (3) Debt obligations distort government policy in debtor countries. (4) The fiscal burden imposed by sovereign debt leads to capital flight and the abandonment of profitable investment opportunities. ${ }^{9}$

These various distortions emerge at different stages in the relationship between borrowers and lenders: (1) when creditors originally make the loans, (2) when debtors face the burden of repaying debt, and (3) when the lending community reacts to those burdens. This section considers what can go wrong with the original contracts and how they can distort behavior in borrowing countries. Section 4 turns to the restructuring of loan contracts in response to these problems.

\subsection{The Loan Contracts: Underborrowing and Overborrowing}

${ }^{9}$ The history of sovereign debt provides episodes in which each kind of event apparently occurred. Problems have been sufficiently dire to lead observers to invoke the term "debt crisis," as during the 1930s and $1980 \mathrm{~s}$. 
If a sovereign debtor has limited incentive to repay its debts, the lending community faces at least two problems in making efficient lending arrangements. One is monitoring and controlling the amount that the country has borrowed in the first place. The second is getting the country to pay.

We illustrate each of these problems, and how they can lead to an inefficient amount of borrowing, with the following simple framework. We consider a country with a gross payoff of $W(L)$ from borrowing an amount $L$, where $W$ is differentiable and increasing and concave in the amount borrowed. The country's net payoff is its gross payoff less its repayment of principal and interest along with any harm $H$ that it suffers for nonpayment.

Potential creditors have access to an international capital market in which they can borrow and lend at a safe gross interest rate $r$. They are competitive and risk neutral, so that any loans that they extend to this country must offer an expected return $r$. In the absence of an enforcement constraint, then, the country would want to borrow an amount $L^{*}$ that equates the marginal gross benefit of borrowing $W^{\prime}\left(L^{*}\right)$ to the cost of capital $r$. This is the efficient loan amount with perfect enforcement. It ensures the country a net payoff $W\left(L^{*}\right)-r L^{*}$, the maximum possible with competitive lending. As we show below, imperfections created by imperfect enforcement can reduce the country's net payoff, both by leading to loan amounts either below or above the efficient level, and by forcing the country to suffer the penalty of default.

Following much of the literature, we assume that the cost to the borrower of not meeting its debt service obligations is an amount $H$, where $H$ may not be known at the time when the loan amount $L$ is extended. Rather, it is drawn from a distribution $F(H)$ and has mean $\bar{H}$. Its actual value is learned, at least by the borrower, before it decides how much to pay its creditors.

While this two-period formulation masks much of the complex dynamics of the interaction between creditors and debtors discussed in the previous discussion, it captures the essential problem raised by sovereign debt: The borrower must receive the loan before it experiences the cost either of repaying or of failing to repay.

Two key issues are the following: (1) Can creditors control the total amount that the country borrows? (2) If the debtor pays less than it owes does it actually suffer the penalty of default? 


\subsubsection{Seniority}

To illustrate how these two problems can distort allocations, we begin by considering a situation in which creditors: (a) collect debt according to seniority and (b) use the threat of the penalty to collect as much as they can (up to what is owed), never actually imposing the penalty. The domestic legal system typically gives loan contracts these features. We show that, under appropriate restrictions on the distribution of the cost of default, they provide the borrower the same net payoff that it would obtain if enforcement were perfect, even though lenders may not collect all that they are owed.

Consider a debtor that has borrowed $L$. We order its debt according to seniority using as an index points in the interval $[0, L]:$ A loan amount with a lower value of this index is senior to a loan with a higher value. The contracted gross interest rate on a loan with seniority $l$ is $R(l)$. We denote the amount owed on all loans senior to it as $\Gamma(l)=\int_{0}^{l} R(j) d j$. Loans are repaid according to their seniority. The debtor's total debt service obligations are $\Gamma(L)$. If $H$ exceeds this amount then the debtor pays all its debts. Otherwise, it pays what it owes up to the amount $H$ according to seniority and defaults on the rest. ${ }^{10}$ There is no further penalty. Competition among lenders ensures that:

$$
R(l)\{1-F[\Gamma(l)]\}=r
$$

for all $l \in[0, L]$. The left-hand side of this expression is the expected payment to the lender who makes a loan with seniority $l$, which is the contracted payment times the probability that the cost of default exceeds the amount to be repaid on senior loans. The right-hand side is the market interest rate.

Loan Supply: Integrating (3.1) from 0 to any total loan amount $L$ by parts indicates that competitive lenders governed by seniority can extend loans up to an amount $\bar{L}=\bar{H} / r$ and still satisfy the zero-profit constraint on each loan. Loans above this amount cannot satisfy the zero-profit condition given that senior loans do.

Loan Demand: The debtor's net payoff is:

$$
W(L)-\Gamma(L)\{1-F[\Gamma(L)]\}-\int_{0}^{\Gamma(L)} H d F(H)=W(L)-r L
$$

\footnotetext{
${ }^{10}$ Note that we abstract from any problems associated with a country's insolvency, or "inability" to pay.
} 
Maximizing this expression with respect to the total loan amount $L$ and the zero-profit condition (3.1) implies that the borrower's net payoff is highest at $L=L^{*}, W\left(L^{*}\right)-r L^{*}$.

If $L^{*}>\bar{L}$ then the borrower will be constrained to borrow $\bar{L}$. It would like to borrow more but will find additional lenders unwilling to extend it loans under any terms whatsoever. If $L^{*}<\bar{L}$ then it will borrow $L^{*}$ and achieve the same payoff that it would under perfect enforcement. ${ }^{11}$

Hence, as long as the expected penalty exceeds $r L^{*}$, seniority with potential partial repayment allows competitive lenders to provide the borrower the same amount of capital and the same net payoff that it would receive if they could enforce repayment perfectly. The loan schedule is upward-sloping in the amount borrowed, with junior debt demanding a higher nominal interest payment. However, the expected interest cost to the debtor is the safe world interest rate, so that it borrows up to the point at which the marginal benefit of borrowing equals the safe rate. The borrower sometimes defaults upon junior loans, but never suffers the default penalty. Creditors use the threat of default to collect payments up to the amount that corresponds to the penalty of default. ${ }^{12}$ What is collected is distributed among creditors according to their seniority.

${ }^{11}$ To say more, we make specific assumptions about the distribution $F(H)$. The Pareto distribution:

$$
\begin{aligned}
& F(H)=1-\left(\frac{\underline{H}}{H}\right)^{\theta}, \theta>0, H \geq \underline{H} \\
& F(H)=0, H<\underline{H} .
\end{aligned}
$$

turns out to be especially convenient. If the penalty has this distribution, then the interest function that solves the zero-profit condition is:

$$
\begin{aligned}
& R(l)=r, L \leq \underline{H} / r \\
& R(l)=r[(1-\theta)(r L / \underline{H})+\theta]^{\frac{\theta}{1-\theta}}, \quad L \geq \underline{H} / r .
\end{aligned}
$$

if $\theta<1$. Note that the interest rate is increasing in $L$ once $r L$ exceeds $\underline{H}$. If $\theta \geq 1$ then any loan amount above $\underline{H}$ will yield an expected loss. No lending above $\underline{H} / r$ occurs.

${ }^{12}$ We discussed negotiations between a debtor and its creditors in Section 2. The outcome we consider here is a special one. It would emerge, for example, if creditors could make a take it or leave it offer, with no possible renegotiation. Refusal by the debtor would lead to its automatic penalization. 
With seniority imposed by the legal system, individual creditors do not need to ration credit to ensure an efficient outcome. They do, however, have to know the debtor country's indebtedness at the time that they lend.

\subsubsection{Credit Rationing with Shared Debt Forgiveness}

While public lending institutions such as the World Bank and IMF regard their loans as senior to those of private lenders, seniority provisions have not been a typical feature of sovereign debt to private creditors. ${ }^{13}$ In place of seniority provisions, debt contracts have typically included pari passu clauses that require the debtor to treat all creditors as equals, giving any individual creditor the right to its pro rata share of any payment made to another creditor.

As we demonstrate here, however, the outcome can still be efficient, but efficiency requires credit rationing.

Loan Supply: If all loans have equal footing then, with partial repayment, the creditor can expect to receive an amount:

$$
R[1-F(D)]-\frac{1}{L} \int_{0}^{D} H d F(H)
$$

for each unit lent, where $R$ is the contractual interest rate, $L$ the amount lent, and $D=R L$ total contractual obligations. Competition among risk-neutral lenders will equate this amount to the safe world interest rate $r$. The implied loan supply schedule has slope:

$$
R^{\prime}(L)=\frac{r-R[1-F(D)]}{L[1-F(D)]}
$$

\footnotetext{
${ }^{13}$ See, for example, the discussions in Alexander (1987) and Detragiache (1993). One reason for their absence is that, as discussed in section 2, a potential cost of default is exclusion from future participation in international capital markets. Enforcing a credit embargo requires the solidarity of the creditors, which seniority is likely to undermine. If partial repayment occurs, junior creditors bear the entire cost of forgiveness but must desist from interfering with the debtor's future credit activity. Another reason is that, as we discuss below, situations can arise in which individual lenders find it in their interest to extend new loans to finance a current payment shortfall. Any creditor who extends new money ex post subordinates its debt to a creditor who does not, even if the creditor extending new debt is legally senior in terms of the original debt. In this context the seniority of the original debt has little meaning. What matters is the relative incentives of the creditors to provide new finance.
} 
which is necessarily positive. The zero-profit condition again implies that the maximum that creditors will lend is $\bar{L}=\bar{H} / \mathrm{r}$.

Loan Demand: The competitive outcome will be an $R$ and $L$ on this schedule that maximizes the borrower's net payoff:

$$
W(L)-D[1-F(D)]-\int_{0}^{D} H d F(H)
$$

Maximizing this amount with respect to $L$ again implies a loan demand of $L^{*}$.

Just as with seniority, the country borrows the minimum of $L^{*}$ and $\bar{L},{ }^{14}$

As Kletzer (1984) emphasizes, either outcome requires that lenders set not only the interest rate, but the total amount of indebtedness. Given the contractual interest rate $R$, the borrower would typically want to borrow more than would be compatible with the zero-profit condition. To avoid making losses lenders cannot lend more than the appropriate $L$. Hence the market cannot achieve this first-best equilibrium if lenders cannot ration credit, as we show in the next section. ${ }^{15}$

\subsubsection{Potential Overborrowing}

To see what difference rationing makes, now assume that competitive lenders can set the contractual interest rate on what they lend, but cannot control how much is borrowed overall. If any borrowing can occur at all, the zero-profit condition and loan supply schedule remain as in the constrained case. However, given the lenders' choice of $R$, the borrower maximizes its expected net payoff, taking $R$ as given. Knowing in advance that the borrower will borrow as much as it wants once they have set $R$, the competitive lenders will set $R$ to be consistent with zero profits. The first-order condition for a maximum, incorporating the zero-profit condition, is then:

\footnotetext{
${ }^{14}$ For the case in which $F(H)$ is Pareto, the zero-profit condition implies the loan supply schedule: $R=(\underline{H} / L)[\theta+(1-\theta)(r L / \underline{H})]^{1 /(1-\theta)}$

${ }^{15}$ In fact, in the early years of large-scale commercial bank lending to developing countries, lenders did not seem to have access to good information on countries' total indebtedness. To the extent that lenders did have information, they did not appear to be coordinating their lending decisions. The World Bank and Bank for International Settlements established reporting systems to address the need for better information, but each system had holes that were filled only after some countries had already run up sizable debts. More recently, banks and official lending institutions seem to have been much better informed about total indebtedness, and to be coordinating their lending more carefully.
} 


$$
W^{\prime}(L)=r-\frac{1}{L} \int_{0}^{D} H d F(H)
$$

The marginal benefit of the loan is strictly below the world cost of capital: The debtor borrows more than it would with seniority or rationing, and more than the efficient amount of borrowing with perfect enforcement. The reason is that each increment borrowed increases the probability of default on existing loans, increasing the interest rate that lenders must charge to earn a zero profit. Since lenders have already set the interest rate when the borrower decides how much to borrow, the borrower does not take into account the effect of its amount of borrowing on credit terms. This externality leads to "too much" borrowing. The borrower suffers from its creditors' inability to ration credit to it, however. While it borrows more, the terms on which it borrows deteriorate to the point that it is worse off. The debtor would benefit from an ability to precommit to a lower level of debt. ${ }^{16}$

\subsubsection{Rationing with Potential Penalization}

So far we have assumed that lenders can use the threat of the default penalty to collect the maximum that the borrower would be willing to pay in order to avoid the penalty. The penalty itself is never invoked. In the context of sovereign debt, however, collecting partial payment can be difficult. One reason is that individual lenders may not control the penalties associated with default. If the cost of not repaying debt is a general loss of creditworthiness, then the market as a whole participates in invoking the penalty. Even if lenders do control the penalty, they may not know the borrower's cost of default when trying to extract payment. At the time that payment was due the borrower would try to claim that the cost of default was the lowest possible realization, and offer to pay no more. If the lender cannot ascertain the borrower's cost of default then the ex ante optimal debt contract would make no provision for renegotiation. ${ }^{17}$ One reason that sovereign debt contracts have been difficult to renegotiate is that the pari

\footnotetext{
${ }^{16}$ For the case in which $F(H)$ is Pareto, the lenders' zero-profit condition again requires $\theta<1$ for any lending to occur at all. The first-order condition for an interior maximum is that $W^{\prime}(L)=r[1-\theta(1-\underline{H} / r L)]$.

${ }^{17}$ This argument assumes, however, that lenders cannot control the imposition of the penalty. If they can, then by applying it with appropriate probability in response to the amount lent, they might be able to extract partial payment from a debtor unwilling to pay all that it owed. Diamond (1984) and Gale and
} 
passu provisions of the debt contracts require that all of a sovereign debtor's creditors agree to any renegotiation of debts. This requirement may make renegotiation difficult because of the free-rider problems that we discuss in Section $4 .{ }^{18}$

Suppose that debt cannot be renegotiated, so that failure to live up to the original loan contract causes the borrower to suffer the default penalty. In the simplest formulation of this problem the borrower suffers the penalty if it pays anything less than the full amount. There is consequently no point in paying anything at all if it does not pay all that it owes. In this case lenders either recover the full amount that they are owed, or nothing.

Continuing to denote the contractual interest rate as $R$, the expected repayment on a loan to a country that has borrowed $L$ is just $R[1-F(D)]$. What debtors can expect to get is $Y=[1-F(D)] D$, which increases or decreases with contractual obligations $D$ depending on the sign of $1-F(D)-D F^{\prime}(D){ }^{19}$

A possibility is that an increase in contractual debt, even though it increases what is paid if repayment occurs, also increases the probability of default to the extent that expected payment falls. A situation in which at some point more debt strictly reduces the total amount that creditors can hope to get has sometimes been called a "debt Laffer curve," although the term is more commonly applied to situations, which we discuss below, in which higher debt obligations reduce payment by distorting decisions in debtor countries. ${ }^{20}$ If a country is on the "wrong" (downward) sloping side of this relationship then creditors can increase their expected receipts by forgiving debt.

If competitive lenders can ration credit, a borrower's indebtedness should never leave the debtor on the wrong side of the Laffer curve. An alternative debt contract that offered the same loan amount at a

Hellwig (1989) discuss the use of penalties in extracting debt repayment and renegotiation. Hellwig (1977) models the time-inconsistency problem facing a lender whose debtor is not paying all that it owes on schedule.

${ }^{18}$ Fernandez and Ozler (1991) have written on the divergent interests of large and small banks in such negotiations.

${ }^{19}$ Eaton and Gersovitz (1994) discuss the sign of this term.

${ }^{20}$ The term is due to Krugman (1989). Sachs (1990), Kenen (1990), Bulow and Rogoff (1990) and Eaton (1990a) discuss the term and its relationship to debt restructuring. 
lower cost would leave the debtor better off at no expense to creditors. Competition among potential creditors would eliminate such dominated contracts.

If lenders ration credit they will choose $R$ and $L$ to maximize the debtor's expected net payoff subject to this zero-profit condition. The first-order condition for a maximum, taking into account the effect of borrowing on the interest rate, is:

$$
W^{\prime}(L)=r\left[\frac{1-F(D)}{1-F(D)-D F^{\prime}(D)}\right]
$$

The equilibrium loan is less than the amount that equates the marginal value of the loan to safe world interest rate. With potential default and credit rationing, there is less lending than would occur with perfect enforcement. ${ }^{21}$

So far, we have shown that with credit rationing with potential default leads to less lending than would occur with perfect enforcement, while unconstrained lending with potential partial payment leads to more lending than with perfect enforcement. What happens if credit markets are subject to both phenomena?

\subsubsection{Unconstrained Borrowing with Potential Penalization}

Say that lenders cannot monitor and control the borrower's total indebtedness, and cannot collect partial payment if repayment incentives are inadequate to enforce full payment. The zero-profit condition and loan supply schedule remain as in the previous section. The difference, as in the case of partial payment, is that now lenders control the contractual interest rate but not total lending. Once they set the interest rate, then the borrower can borrow all that it wants at this rate. Its optimal indebtedness, taking the interest rate as given, satisfies, upon substitution of the zero-profit condition:

$$
W^{\prime}(L)=r
$$

${ }^{21}$ When $F(H)$ is Pareto, the loan supply schedule is $R(L)=\left[r(L / \underline{H})^{\theta}\right]^{1 /(1-\theta)}$ and the equilibrium loan amount satisfies $W^{\prime}(L)=\frac{r}{1-\theta}$. As before, any lending at all beyond $\underline{H} / r$ requires that $\theta<1$. 
While unconstrained borrowing by itself leads to more borrowing than would occur with perfect enforcement, and potential default leads to less, together the two effects cancel, and the same amount is borrowed as would be the case if enforcement were perfect.

The borrower is less well off, however, since it suffers the penalty of default with positive probability. The borrower is even worse off than if credit were rationed. With rationing the borrower is at its highest possible net welfare given the loan supply schedule Without rationing it remains on this schedule, but borrows more at a higher contractual interest rate.

\subsubsection{A Digression: Sovereign Debt and the Social Cost of Capital}

The cases discussed indicate how problems associated with sovereign debt can cause the marginal product of capital, and hence the social cost of capital, to diverge from the world cost of capital. The direction of the divergence is ambiguous, however. Potential repudiation acts to make the marginal product of capital exceed the world interest rate, while lenders' inability to subordinate junior debts or to ration credit has the opposite effect.

Moreover, there is no clear relationship between the contractual interest rate and the social cost of capital. Consider the case with credit rationing and potential penalization If the default penalty follows a Pareto distribution with parameter $\theta=1 / 2$ and lower bound $\underline{H}$ then the marginal product of capital will equal twice the world interest rate, or $2 r$. The contractual interest rate is then lower than the marginal product of capital if $r L<2 \underline{H}$ but exceeds it once the relationship equality is reversed. Thus, in economies where capital is highly productive (as measured by the amount of borrowing that equates the marginal product to $2 r$ ) relative to the incentive to repay debt (as measured by $\underline{H}$ ), the contractual interest rate will overstate the contribution of an additional unit of capital. In economies that have less ability to use capital relative to their incentive to repay the contractual interest rate understates the marginal product of capital.

\subsubsection{Do Creditors Penalize Default?}


When countries fail to repay, do they suffer? The evidence.is ambiguous. Eichengreen (1989) and Lindert and Morton (1989) find that defaulting in the 1930s did not hurt a country's credit terms in the 1970's. Ozler (1993), however, finds that this result is sensitive to these authors' inclusion of countries that did not exist in the 1930s in their analysis. Within a fixed sample of countries, those that defaulted did worse than those that did not. Countries that came into being only after the 1930 s were treated more like defaulters from the earlier period than like repayers from that period, suggesting that countries earn better credit terms by repaying previous loans rather than suffer worse credit terms as a consequence of defaulting on previous loans. ${ }^{22}$

Cohen (1992) examines the growth experience of debtor countries in the 1980s. While these countries all suffered a slowdown in growth, he concludes that repaying debt or failing to repay debt had little effect on growth once factors like the terms of trade and domestic investment are taken into account.

\subsection{Debt and Domestic Distortions}

One concern raised by sovereign debt is that the debt itself might distort the incentives of borrowing country governments in a way that is detrimental to their own or to their creditors' welfare. As discussed in section 2, a common assumption has been that the incentive to repay increases with the debtor's output at the time that debt repayment is due. Steps that the borrower takes to increase its future output then increases what it is expected to pay. Debt thus acts as a marginal tax on the return to investment, giving debtor countries greater incentive to consume rather than to invest available resources. ${ }^{23}$

Another assumption is that default disnupts the debtor's trade. Hence, by allocating resources to reduce the gains from trade, such as investing in import-competing rather than export activities, a debtor reduces its vulnerability to trade disruption and its incentive to repay debt. ${ }^{24}$ In fact, a common

\footnotetext{
22Eaton (1990b) develops a model with this implication for the evolution of credit terms.

${ }^{23}$ Sachs and Cohen (1985) provide an early statement of the proposition that debt provides an incentive to use resources for current consumption rather than for investment.

24 Goldberg and Spiegel (1992) develop a two-sector model of borrowing and repayment. Creditors can seize the output of one sector but not the other. Having borrowed, the sovereign has an incentive to shift investment toward the sector that is out of the creditors' reach.
} 
observation has been that large debtor's focused their investments in import-competing and nontraded goods sectors rather than in export sectors. ${ }^{25}$

We extend the analysis above to demonstrate how foreign debt can distort a debtor's behavior. For concreteness we consider the case in which lenders can ration credit and collect the most that the debtor is willing to repay. A key issue is the timing of decisions, in particular, whether the debtor acts before or after it borrows.

We now allow the debtor's payoff gross of debt repayment and default costs to depend not only on the amount that it borrows, but upon some action $\gamma$ over which it has control. This action, for example, could be overall investment, or the share of investment devoted to the export sector. Hence the borrower's gross payoff is now $W(L, \gamma)$, which is differentiable, increasing and concave in the loan amount $L$, and concave in the action $\gamma$. We assume that $\gamma$ achieves an interior maximum $\gamma^{*}$, which is the level that the borrower would choose in the absence of debt considerations, or with perfect enforcement.

We also allow $\gamma$ to affect repayment incentives, however. The distribution of the cost of default $H$ is now $F(H, \gamma)$. We assume that $F$ is decreasing in $\gamma$, meaning that this action increases the likelihood that high values of the default penalty will be realized. Hence, other things equal, a debtor that chooses a higher level of $\gamma$ has a greater incentive to repay.

The borrower's net payoff is now:

$$
W(L, \gamma)-D[1-F(D, \gamma)]-\int_{0}^{D} H F_{H}(H, \gamma) d H,
$$

where $D=R L$ is the debtor's contractual debt obligations. The lender's zero-profit condition becomes:

$$
R[1-F(D, \gamma)]+\frac{1}{L} \int_{0}^{D} H F_{H}(H, \gamma) d H=r .
$$

Differentiating this expression with respect to $\gamma$ and integrating by parts yields:

$$
R_{\gamma}=\frac{\int_{0}^{D} F_{\gamma}(H, \gamma) d H}{1-F(D, \gamma)}
$$

${ }^{25}$ See, for example, Diaz-Alejandro (1985). 
which falls as $\gamma$ rises. Hence, not surprisingly, the debtor improves its credit terms by taking an action that increases the cost of default.

\subsubsection{Commitment to Policies}

Say that the borrower can decide about $\gamma$ before lenders determine their credit terms. It will then take into account the effect of its choice on the credit terms that it will then get. If the loans are demand determined, so that $W^{\prime}(L)=r$, then the debtor has no incentive to modify its choice of policy to affect credit terms, so will continue to set $\gamma=\gamma^{*}$.

If, however, loans are supply constrained at $\bar{L}=\bar{H} / r$ then the optimal choice of $\gamma$ is determined by the condition:

$$
W_{\gamma}(L, \gamma)=\left[W_{L}(L, \gamma)-r\right] \frac{\int_{0}^{\infty} F_{\gamma}(H, \gamma) d H}{r}
$$

Since higher values of $\gamma$ shift the distribution of the default penalty upward, the term on the right of this expression is negative, implying that the optimal value of $\gamma$ exceeds what it would be with perfect enforcement. If the borrower can commit to an action that influences its cost of default before credit terms are set, it should modify its action to increase its expected cost of default. It will benefit by improving its credit terms. ${ }^{26}$

\subsubsection{Lack of Commitment}

Say instead that the borrower can decide on $\gamma$ only after it has taken out loans. At that point its interest rate $R$ and loan amount $L$ are given. Hence the borrower ignores the impact that $\gamma$ would have on them, even though creditors may have correctly anticipated its choice of $\gamma$ when setting loan terms.

The borrower's first-order condition for an optimal choice of $\gamma$ is now:

$$
W \gamma=-\int_{0}^{D} F_{r}(H, \gamma) d H
$$

\footnotetext{
${ }^{26}$ If the borrower cannot be rationed or suffers the default penalty rather than making partial payment, it has further incentive to try to commit to policies that improve its credit terms. These cases are left as exercises for the interested reader.
} 
The term on the right is now positive. Since a lower choice of $\gamma$ reduces what debtor can expect to pay, it sets $\gamma$ below $\gamma^{*}$. Hence, if the borrower takes an action that influences its cost of default only after credit terms are established, then it will modify its action to reduce its expected cost of default.

To summarize, a debtor has reason to modify its actions to increase its incentive to repay if it can commit to taking these actions before credit terms are established. Once credit terms are set, however, the direction of the incentive is reversed: The debtor has an incentive to modify its actions to reduce its incentive to repay. ${ }^{27}$

\subsubsection{Was There a Debt Laffer Curve?}

The "debt Laffer curve" argument holds that debt distorts decisions in debtor countries so much that a reduction in contractual debt can increase what creditors can hope to receive. The question remains as to why so much was lent in the first place.

Cohen (1990) uses the secondary market price of debt to estimate the relationship between the market value and nominal value of debt for 16 highly indebted countries. A "debt Laffer curve" would imply that, at some point, an increase in the value of nominal debt would be associated with a decrease in the market value of the debt. He could not reject the hypothesis that the relationship between nominal and market value was positive in the relevant range for all countries in the sample. ${ }^{28}$

\subsection{The Fiscal Problem}

Most of the debt that developing countries ran up during the 1970s and 1980s was incurred or guaranteed by the governments of these countries. One reason for the prominent role of the government might have been creditors' suspicions about the local judicial system's ability or willingness to enforce a

\footnotetext{
${ }^{27}$ One interpretation of the conditionality that the IMF imposes on borrowers is a means of enforcing borrowers' commitments to actions that improve their credit terms with private lenders. By borrowing from the IMF, a country exposes itself to punishment should it not take these actions, enhancing its commitment to taking them.

${ }^{28} \mathrm{~A}$ possible explanation is that the markets foresaw subsequent debt reductions in cases where the relationship between nominal and market values became negative. This explanation would imply, of course, that markets expected an efficient outcome.
} 
loan contract with a private debtor. Even in cases where debt was initially nonguaranteed, private creditors turned to the government to make good on loans that went sour. ${ }^{29}$

An implication of the government's role as primary debtor, or as implicit or explicit guarantor of private debt, is that debt came to represent a significant potential tax burden on the economy. One impact that this burden might have had is to discourage subsequent investment and output.

\subsubsection{Government Debt and the Strategic Complementarity of Private Investment}

Eaton and Gersovitz (1988) develop a model to show how government debt incurred to finance public investment can harm credit terms and potentially discourage private investment. An implication is that, by increasing the potential tax burden on private investment domestically, government debt can discourage private investment and give rise to capital flight abroad.

In their model the government must borrow to invest in inftastructure, and uses revenue from taxes on income from subsequent production to finance repayment. If there is a large amount of domestic investment then the tax base suffices to finance repayment and provide investors a return that is competitive with that abroad. But if the amount of investment is too small then the government must tax what investment there is at such a high rate that the after-tax domestic return is no longer competitive.

There can be two locally stable equilibria. In one the level of investment is sufficient to allow the government to finance its debt burden and still provide private investors a competitive rate of return. The government fully repays its debt. The other equilibrium is one in which private investment is zero, and the domestic rate of return on domestic investment is strictly less than the world interest rate. The government can repay only a part of its debt.

The reason for the multiplicity of equilibria is that the tax burden on capital implied by the government debt creates a "strategic complementarity" among private investors. Over a range, an

${ }^{29}$ Diaz-Alejandro (1985) recounts the Chilean government's experience with foreign commercial banks that held it accountable for loans to local private banks that went bankrupt. The foreign banks demanded that the government assume the debts or face worsened credit terms itself. The Chilean government acquiesced and assumed the debts in question. Hence the creditors acted as if a government guarantee was implicit in their lending to private parties. 
increase in investment by any single investor increases the after-tax return to other private investors by reducing their tax burden ${ }^{30}$

\subsubsection{Debt Guaranties and Moral Hazard}

Eaton (1987) extends the analysis to show that explicit or implicit government guarantees of loans to private entities can lead to overborrowing and encourage the flight of nationally-owned capital abroad. Again, crucial assumptions are that at least part of the burden of financing debt service will fall on domestic investment, and that domestic capital, by fleeing abroad, escapes taxation at home.

Say that the economy has a large number $n$ of domestic investment projects, each one associated with a risk-neutral entrepreneur. For simplicity, assume that the projects and entrepreneurs are identical. Conditional upon an investment level $k$ and its entrepreneur putting in effort, each project yields an amount $f(k)$ with probability $\lambda$ and 0 with remaining probability. If the entrepreneur does not put in effort then output is 0 for sure. Putting in effort costs the entrepreneur an amount $\beta$ in terms of income. The entrepreneur owns capital in amount $\bar{k}$ and borrows an additional amount $l$ at rate $R$. If the project succeeds the entrepreneur pays back debt, pays a tax $t$, and keeps the rest. If the project fails the entrepreneur goes bankrupt, and pays neither debt nor taxes.

The entrepreneur can also invest his or her own capital abroad, escape taxation, and earn a return $r^{\prime}$ which might, because of evasion costs, fall short of the safe world borrowing rate $r$. However, as long as:

$$
\lambda[f(\bar{k}+l)-R l-t]-\beta>r^{\prime} \bar{k}
$$

it will pay the entrepreneur to invest in the domestic project and put in effort to ensure its success.

Otherwise, the entrepreneur is better off investing abroad and not bothering to put in effort on the project. Foreign lending occurs before entrepreneurs decide where to invest their own capital and how much effort to put into their projects.

\footnotetext{
${ }^{30}$ Dooley and Kletzer (1994) provide a very general model relating capital flight to external debt and tax policies in debtor countries.
} 
In the absence of any loan guarantees or taxes, competitive foreign lenders will be willing to lend at rate $r / \lambda$ if they expect that the entrepreneur has an incentive to put in effort. The entrepreneur has this incentive as long as the above condition holds at this rate and at a zero tax.

Say, however, that foreign lenders require a loan guarantee from the local government. One reason to do so is their inability, relative to the government, to distinguish failed projects from successful ones whose owners are feigning failure to keep the total return for themselves. These guarantees are financed by a tax on successful projects. Let $\boldsymbol{m}$ denote the number of projects whose entrepreneurs invest abroad and fail to put in effort. Financing failed projects thus requires a tax:

$$
t=\frac{m+(1-\lambda)(n-m)}{\lambda(n-m)} R \bar{l}
$$

on each successful project, where $\bar{l}$ is the loan to the average entrepreneur.

Again, there can be two equilibria. In one, all entrepreneurs put effort into their projects and invest domestically. The tax rate is $(1-\lambda) / \lambda$. Output is $\lambda n f(\bar{k}+l)$. All lenders are repaid, by the entrepreneur if his project succeeded, or by the government if it failed. In the other, entrepreneurs invest abroad and do not put effort into their projects. The government reneges on its loan guarantees. Lenders are not repaid. Output collapses.

Say that the high-output equilibrium occurs with probability $\omega$. With loan guarantees, riskneutral lenders will charge an interest rate $r / \omega$, since the risk that they now face is not the failure of a specific project but the realization of the bad equilibrium. Facing this interest rate, entrepreneurs will borrow to satisfy the first-order condition: ${ }^{31}$

$$
\operatorname{cof}^{\prime}(\bar{k}+l)=r \text {. }
$$

\footnotetext{
${ }^{31}$ Note that this condition implies more borrowing than the level that maximizes national income, which equates the expected marginal product to the world interest rate, or:, $\omega \lambda f^{\prime}(\bar{k}+l)=r$.

The reason for the discrepancy is that, with loan guarantees, an individual borrower does not bear the full cost of his loan. More borrowing generates a negative externality on other borrowers who must make good on the guarantee if the entrepreneur's own project goes bad. Since credit terms no longer reflect the possibility of failure of the individual project, there is again an incentive to "overborrow."
} 
While these models are extreme in their assumptions and implications, they illustrate how a government role as a debtor, or guarantor of private debt, can create interdependence in lending and investment behavior. An outcome can emerge in which the potential tax obligations implied by the debt discourage entrepreneurial activity and lead to capital flight.

\section{What Can Be Done?}

Having discussed various problems that sovereign debt can create, we now turn to policies that have been proposed and, on occasion, implemented to alleviate these problems. Since the latter part of the 1980 s and 1990s have been periods in which the major debtor countries have been making net transfers to their private creditors, the focus of much of the more recent literature has been on the disposition of outstanding debt rather than on why the loans were ever made in the first place. In this section we consider means of alleviating existing debt problems, grouping proposed solutions into three categories: those initiated by private creditors, those initiated by the debtors, and those initiated by the international public sector. In the concluding section we turn to the nature of debt contracts themselves, and discuss the extent to which alternative institutional arrangements for providing developing countries access to international capital markets might have avoided the problems that emerged.

\subsection{Creditor Initiatives}

Consider the options facing a creditor in dealing with a debtor that is not paying all that it owes. There are four basic choices that can be applied separately or in combination:

1. Seeking legal remedy. The debtor could appeal to the judicial system to declare the debtor in default. Such a declaration would give the creditor the right to any assets of the debtor within the jurisdiction of the legal system. This claim would not only transfer existing assets to the creditor, but would impede subsequent transactions between the debtor country and agents in the jurisdiction of the creditor.

The first consequence harms the debtor and benefits the creditor only to the extent that the debtor has assets abroad. To the extent that the debtor is a net debtor, these assets will not suffice to cover the claims against it. The second consequence is more likely to discourage the debtor from engaging in 
intertemporal and intratemporal trade than to result in any transfer to the creditor. Unlike the transfer of assets to the creditor, this second consequence is likely to constitute a deadweight loss.

Hence the creditor's limited ability to seize the debtor's assets renders the legal remedies available to creditors much less effective than in a domestic context. In fact, the creditors of sovereign debtors have rarely turned to their judicial system for redress. They have typically pursued the other options discussed below. Nevertheless, creditors' ability to pursue legal remedies, and thereby impose significant costs on the debtor, has undoubtedly had a significant effect on debtor behavior. ${ }^{32}$

2. Lending the Difference. The creditor can lend the debtor the difference between what it owes and how much it is willing to pay. Formally, lending could mean making new loans, often called, in the context of the debt crisis, "new money," rescheduling payments on existing loans, or tolerating arrears.

Obviously this option only postpones ultimately dealing with the debtor's payment problems. ${ }^{33}$ It makes sense if the creditor thinks that the debtor's repayment prospects will improve in the future. It also makes sense if the creditor thinks that pursuing one of the other options may be more fruitful later on.

3. Forgiving the Difference. The lender can forgive the debtor the difference between what it owes and how much it is willing to pay. This option makes sense if the creditor thinks that the borrower is unlikely ever to pay the amount forgiven and that forgiving some debt increases the prospects for repayment of what remains.

4. Getting Someone Else to Lend the Difference. It would seem unlikely that other lenders would find additional lending more attractive than the initial lender. In fact, the initial lender may have reason to lend to keep alive its hope of repayment on its initial debt. Other lenders do not have this reason to lend. As we discuss in Section 4.3, however, in the context of sovereign debt official lending institutions may have an incentive to assume debts in order to avoid the cost that default might impose upon the world economy as a whole.

\footnotetext{
${ }^{32}$ Kaletsky (1985) and Alexander (1987) discuss legal remedies in the case of sovereign default. Bulow and Rogoff (1989a) model the implications of these remedies for loan market equilibrium.

${ }^{33}$ Unless the lender intends always to roll over debts in the future, in which case it is really forgiving the debt (option 3).
} 
We adopt the framework we developed in Section 3 to illustrate the creditors' options. We expand the repayment period to two periods in order to illustrate the relevant dynamics, and ignore the initial lending decision, which at this point is a bygone. Consider the situation of a debtor that currently owes its private creditors an amount $D_{0}$ but is willing to pay at most $H_{0}<D_{0}$. In a subsequent period, period 1 , it is willing to pay, up to what it owes, an amount $H$ which is currently unknown by anyone, but is expected to be drawn from a distribution $F(H, \gamma)$, where $\gamma$ is a decision made by the creditor in the current period. Again, we assume that larger values of $\gamma$ increase the likelihood of repayment, so that $F_{\gamma}<0$. The debtor's payoff each period $i$ is a function $U^{i}\left(T_{i}, \gamma\right)$ of its net transfer to the creditor that period, $T_{i}$ and its choice of $\gamma$. At the beginning of period 0 the creditor owes $D_{1}$ in period 1 .

\subsubsection{A Single Creditor}

To illustrate the first three options we initially assume that there is a single creditor (or a unified consortium of creditors). Its objective is to maximize the discounted value of what the debtor transfers to it over two periods, or $T_{0}+\beta^{c} T_{1}$, where $\beta^{C}$ is the creditor's discount factor. We turn to the problems raised by multiple creditors in the next section.

Seeking a legal remedy will be worthwhile only if the creditor's expected net benefit from the anticipated remedy exceeds $H_{0}$. For reasons that we have discussed, in the case of sovereign debt this may be unlikely.

Consider now the second and third options. Denote the amount of any new lending in period 0 by $N$ and the amount of debt forgiven in period $i$ by $F_{i}$. By definition, the difference between what the debtor owes and what it pays in period 0 is either rolled over or forgiven, so that $D_{0}-T_{0}=N+F_{0}$. Let $R$ denote the gross interest rate on new lending. Period 1 debt becomes $D=D_{1}-F_{1}+R N$.

All that matters to either party is the actual amount transferred in period $0, T_{0}=D_{0}-F-N$, and what happens to debt outstanding at the beginning of the next period, $D=D_{1}-F_{1}+R N$. Depending on the credit terms that apply to new loans, the same levels of $T_{0}$ and $D$ can be achieved with many different combinations of refinance and forgiveness. We can state the problem, then, in terms of these magnitudes. The debtor's expected welfare is: 


$$
\max _{\gamma} U^{0}\left(D_{0}-T_{0}, \gamma\right)+\beta^{D}\left\{[1-F(D, \gamma)] U^{1}(D, \gamma)+\int_{0}^{D} U^{1}(H, \gamma) F_{H}(H, \gamma) d H\right\}
$$

while the creditor's payoff is:

$$
T_{0}+\beta^{C}\left\{[1-F(D, \gamma)] D+\int_{0}^{D} P F_{H}(H, \gamma) d H\right\}
$$

The creditor, then, wants to restructure debt so that the consequent current net transfer $T_{0}$ and payment the next period maximize its payoff subject to the constraint that $T_{0} \leq P_{0}$.

If $T_{0}$ and $D$ have no bearing on the debtor's choice of $\gamma$ then the creditor does best by setting $T_{0}=P_{0}$ and $D$ as high as possible. The literature, however, has focused on the role of debt in distorting the debtor's incentives to undertake policies conducive to repayment. First-order conditions for an interior maximum are then:

$$
\begin{aligned}
& \frac{d Y}{d T_{0}}=1-\beta^{C} \int_{0}^{D} F_{\gamma}(H, \gamma) d H \frac{d \gamma}{d T_{0}} \\
& \frac{d Y}{d D}=\beta^{C}\left\{[1-F(D, \gamma)]-\int_{0}^{D} F_{\gamma}(H, \gamma) d H \frac{d \gamma}{d D}\right\} .
\end{aligned}
$$

Hence the creditor will want to modify its choices to try to encourage the debtor to choose a higher value of $\gamma$.

How do credit terms affect the debtor's choice of $\gamma$ ? Differentiating the debtor's first-order condition for its best choice of $\gamma$, and invoking the second-order condition, indicates that $d \gamma / d T_{0}$ has the same sign as $U_{T \gamma}^{0}\left(T_{0}, \gamma\right)$, and that $d \gamma / d D$ has the same sign as:

$$
-F \gamma(D, \gamma) U_{T}^{1}(D, \gamma)+[1-F(D, \gamma)] U_{T \gamma}^{1}(D, \gamma)
$$

The first result simply means that the creditor has an incentive to reduce its demand for current payment if paying less now raises the debtor's utility from taking an action that increases its repayment prospects in the future.

The implications of the second result are more complicated. The first term is necessarily negative: Higher debt gives the debtor less incentive to reform by reducing its utility in situations where it pays everything. The sign of the second term is that of the cross-partial $U_{T_{\gamma}}^{1}(D, \gamma)$, which is positive if paying less in the future raises the debtor's utility from reforming, and negative if paying less in the future 
lowers its utility from reforming. The typical assumption in the literature is that creditors' "tax" a portion of any of the benefits of reform, so that the target's incentive to reform diminishes as its debt increases. ${ }^{34}$

But simple and plausible alternatives yield different conclusions. Continuing the example introduced in Section 3, let $F(H, \gamma)$ have the Pareto distribution:

$$
F(H, \gamma)=1-\left(\frac{\gamma \underline{H}}{H}\right)^{\theta} \quad \theta \in(0,1)
$$

Say that the borrower's utility each period is an increasing, concave function of output less transfer payments to creditors less reform effort $\gamma$. Output in the earlier period is given at $y_{0}$ while output in the later period is an increasing, concave function of $\gamma, y(\gamma)$. The borrower's expected payoff over the two periods is then:

$$
\max _{\gamma} u\left(y_{0}-\gamma-T_{0}\right)+\beta^{D}\left\{\left[u(y(\gamma)-D]\left(\frac{\gamma \underline{H}}{D}\right)^{\theta}+\int_{\gamma \underline{H}}^{D}\left[u(y(\gamma)-H] \theta(\gamma \underline{H})^{\theta} H^{-\theta-1} d H\right\}\right.\right.
$$

In this case a reduction in the transfer demanded in period 0 definitely increases the borrower's incentive to reform. The reason is that reforming uses up current resources, raising the marginal utility of current relative to future consumption. Lowering current debt-service obligations, by lowering the marginal utility of period 0 consumption, increases the incentive to undertake reform.

The effect of lowering future debt service obligations depends upon the sign of the expression:

$$
\frac{\sigma y^{\prime}(\gamma)}{y(\gamma)-D}-\theta
$$

where $\sigma=-u^{\prime \prime}(y(\gamma)-D)(y(\gamma)-D) / u^{\prime}(y(\gamma)-D)$, the elasticity of the marginal utility of period 1 income. If reform lowers period 1 output $\left(y^{\prime}(\gamma)\right.$ negative), then reducing debt again necessarily increases the incentive to reform. If reforms raise later output, however, then increasing debt raises the incentive to reform if the utility function is highly concave ( $\sigma$ large) and output highly responsive to reforms. The reason is that higher debt acts to raise the marginal utility of consumption in the later period, increasing the incentive to undertake reforms that transfer income to the later period. ${ }^{35}$

${ }^{34}$ See, for example, Sachs (1984), Krugman (1988), Froot (1989), and Claessens and Diwan (1990). ${ }^{35}$ Corden (1989) points out the generally ambiguous relationship between the level of debt and the incentives to undertake reforms that increase the probability of paying off the debt. 
It might seem that competition among lenders would prevent initial creditors from refinancing at terms that yield supernormal profits on the additional funds. However, the original loan contracts typically prohibit the debtor from borrowing from outside creditors, giving the initial creditors a monopoly on any further lending to the borrower. ${ }^{36}$

To summarize, a creditor's best response to a shortfall in debt service depends upon the implications of a larger future debt burden for repayment prospects. As long as the debtor remains on the upward sloping part of its "debt Laffer curve" in future periods then the creditor should refinance at the highest possible terms. These terms could even yield supernormal returns if the original creditor can bar other creditors from lending to the distressed debtor. If the debtor is near the peak of the curve in future periods, however, then the creditor would do better to provide additional finance at concessionary terms. If the debtor is already over the top then the creditor should simply forgive the current shortfall and reduce future debt as well.

\subsubsection{Multiple Creditors}

So far, the discussion has assumed a single creditor or a group of creditors who can act in concert. Much of the concern about creditors' response to debt problems derives from the potential inability of a diffuse and diverse set of lenders to reach an agreement about restructuring debt. One concern is that individual lenders, even if they have similar characteristics, will be unable to coordinate an efficient response. Another is that their interests might diverge, preventing them from reaching an agreement. We treat each in turn.

\section{The Coordination Problem}

The following example illustrates the problem of coordinating the refinance of a payments shortfall among multiple lenders, even when they are identical in terms of their preferences and

\footnotetext{
${ }^{36}$ The expected benefit of future monopoly power over the creditor should have been reflected in the terms of the initial loans. Ozler (1989) finds that reschedulings during the 1970 s were typically associated with an appreciation of the equity value of the creditor banks involved, suggesting that the banks were using the debtors' payment problems to exploit their monopoly position during this period. During the $1980 \mathrm{~s}$, however, reschedulings had the opposite effect on the equity value of the banks.
} 
exposure. ${ }^{37}$ As before, we consider a borrower who currently owes an amount $D_{0}$ but is willing to pay only $H_{0}$. What it is willing to pay subsequently is drawn from a distribution $F(H)$, and what it currently owes that period is $D_{1}$. Assume now, however, that there are $\mathrm{N}$ creditors who happen to have the same level of initial exposure.

In period 0 , then, each creditor $j$ receives an amount $H_{0} / N$ and must decide what interest rate $R_{j}$ to charge on what it must refinance, which is $\left(D_{0}-H_{0}\right) / N .{ }^{38}$ To introduce a "debt Laffer curve" in its simplest form assume that repayment in the second period is an all or nothing event, so that if the debtor is unwilling to pay all that it owes it pays nothing and suffers the consequence of default. In this case, what an individual creditor can expect to receive next period, as a function of its own and other lenders' finance terms, is:

$$
Y_{i}=\left[1-F\left(D_{1}+\frac{D_{0}-H_{0}}{N} \sum_{j=1}^{N} R_{j}\right)\right] \frac{D_{1}+\left(D_{0}-H_{0}\right) R_{i}}{N}
$$

An interior Nash equilibrium in refinance terms (if it exists) is one in which each lender chooses a refinance rate $R$ that satisfies the first-order condition:

$$
[1-F(D)]-F^{\prime}(D) D / N=0
$$

where $D=D_{1}+\left(D_{0}-H_{0}\right) R$, the total amount owed in period 1. Ultimate period 1 indebtedness thus increases with the number of creditors, and exceeds the amount of debt that maximizes expected repayment unless $N=1$. As $N$ approaches infinity the equilibrium amount of debt implies almost certain default. Hence uncoordinated refinancing necessarily puts the debtor over the top of the debt Laffer curve, if it has a top. The reason is that higher interest costs impose a negative externality on other creditors by increasing the likelihood of default on their loans. The result relates to that on the potential for overborrowing when uncoordinated lenders cannot ration credit or impose seniority.

${ }^{37}$ Cooper and Sachs (1985), Krugman (1988), Detragiache and Garella (1993), and Spiegel (1993a) model the public goods problem posed by debt forgiveness.

38 Note that this choice encompasses both refinance at competitive terms and total forgiveness of the current shortfall. Denoting a creditor $i$ 's choice by $R_{i}$, for example, full forgiveness implies $R_{i}=0$ while $R_{i}$ negative implies not only full forgiveness of the current shortfall and relief of future debt as well. 
If the penalty of default is uniformly distributed on the interval $[0, \bar{H}]$, for example, then the "debt Laffer curve" peaks at a period 1 debt of $\bar{H} / 2$. The Nash equilibrium in credit terms leaves the debtor a total period 1 debt of $N \bar{H} /(N+1)$. Expected total repayment is $N \bar{H} /(N+1)^{2}{ }^{39}$

Secondary debt markets, which we discuss in greater detail in Section 4.2, provide a natural coordination mechanism. Diffusely held, the debt in our example is worth only $N \bar{H} /(N+1)^{2}$. If a consolidator could buy it up at this price and reduce its nominal level to the peak of the "debt Laffer curven $^{n}$ the expected yield would be $(N-1)^{2} \bar{H} /\left[4(N+1)^{2}\right]$. A reason given for the failure of this mechanism is the incentive for an individual investor to hold on to its own claim and demand a higher price, dissipating the consolidator's return. Various methods of purchase might still allow a potential debt consolidator to achieve a gain. One mechanism is to make any purchase contingent on participation by a broad range of creditors. By holding out, then, an individual creditor would kill the whole deal. In fact, a number of the debt restructuring schemes contain such "participation clauses" to avoid free riding on the consolidator.

\section{The Heterogeneity Problem}

Things can get potentially even worse if lenders have different attributes. Differences that have received attention are those between large and small lenders (Spiegel, 1992; Fernandez and Ozler, 1991) and sound and unsound lenders (Demirguc-Kunt, Diwan, and Spiegel, 1993). We discuss the implications of each in turn.

Consider the Nash equilibrium in refinancing above. Assume, however, that creditors differ according to their initial exposure. Small lenders have greater incentive to free ride, so will refinance at a higher rate (or, equivalently, forgive a smaller share) than large lenders. Moreover, their superior ability to free ride means that small lenders do better in the Nash equilibrium than their share of exposure would imply. A consequence is that in any negotiations between large and small lenders about

\footnotetext{
${ }^{39}$ The Pareto distribution fails to illustrate this result. The reason is that, with this distribution, expected repayment is monotonically increasing or decreasing in the amount owed; there is no nondegenerate "debt Laffer curve."
} 
refinancing the debt, small lenders might successfully demand more than what their share of exposure would indicate. Similarly, they might demand a higher price per unit of their debt. Descriptions of loan restructurings indicate that small lenders did indeed tend to take a much harder line than large lenders.

Fernandez and Kaaret (1992) formally analyze the potential inefficiencies that the coexistence of large and small creditors can introduce. They examine negotiations between a sovereign debtor and its large creditors to restructure debt. ${ }^{40}$ The debtor does not know how much the large banks can pressure the country's small creditors into reaching an agreement. They show how this informational asymmetry, for the reasons given in Kreps and Wilson (1982), can delay any agreement between the debtor and the large creditors, possibly for many periods. ${ }^{41}$

Fernandez and Ozler (1991) model bargaining between a debtor and large and small creditor banks. Only large banks have the ability to punish a recalcitrant debtor, but at a cost borne only by them. Since the benefits of repayment are distributed pro rata, the maximum penalty that the lenders can credibly threaten collectively increases ceteris paribus with the concentration of debt in the hands of the large banks. Their empirical analysis confirms that the secondary market price of a country's debt is positively correlated with the proportion of the country's debt held by big banks.

Some of the banks involved in sovereign lending have had solvency problems of their own. For reasons explained by Stiglitz and Weiss (1981), the prospect of bankruptcy creates an incentive to take greater risk. This incentive has implications for how risky lenders might restructure debt. Consider again the problem of restructuring debt to provide the debtor country the incentive to undertake policies that improve prospects for repayment, assuming now that the creditor can get whatever the debtor is willing to pay. Say, however, that the creditor itself will go bankrupt if the debtor pays less than some minimum amount $\underline{T}$. The creditor does not care about repayment amounts less than this since it won't be around to collect. It will want to set repayment terms to satisfy the first-order conditions:

\footnotetext{
${ }^{40}$ Normally, the syndicate of lenders was represented by the largest creditors at debt negotiations, but final agreement required the assent of all.

${ }^{41}$ Armendariz de Aghion (1990) uses a similar model to explain why only major debtors received new loans following the onset of the debt problems of the 1980 s.
} 


$$
\begin{aligned}
& \frac{d Y}{d T_{0}}=1-\beta^{C} \int_{\underline{T}}^{D} F_{\gamma}(H, \gamma) d H \frac{d \gamma}{d T_{0}} \\
& \frac{d Y}{d D}=\beta^{C}\left\{[1-F(D, \gamma)]-\int_{\underline{T}}^{D} F_{\gamma}(H, \gamma) d H \frac{d \gamma}{d D}\right\} .
\end{aligned}
$$

Comparing these with the incentives facing a sound lender, the risky lender has less incentive to reduce obligations to encourage reform. The reason is that it does not benefit from reform at low levels of payment.

This argument suggests why banks in precarious positions have less incentive to restructure debt than sound banks, and why risky banks might hold on to sovereign loans while sounder banks are unloading them. It also indicates why unsound banks might take a harder line in negotiations among lenders to restructure debt. Finally, it suggests why it might be hard for an individual creditor to consolidate debt if it does not know the relevant characteristics of the current creditors. They would have an incentive to overstate their valuation of the debt in order to get a higher price.

\subsection{Debtor Initiatives}

Another approach to solving debt problems has been to allow the debtor to take the initiative in restructuring its debt by buying it back on the secondary market. ${ }^{42}$ Buybacks have taken numerous forms, depending on how they are financed. In their purest form, the debtor government buys back the debt with its own foreign exchange. In other cases foreign donors have provided the resources. In "swap" arrangements the debtor government has exchanged domestic currency for debt at some specified price. The use of this currency has usually been tied to some particular purpose, such as direct foreign investment (debt-equity swaps) or environmental protection (debt-for-nature swaps). These swap arrangements can be thought of as a combination of a pure buyback in combination with a subsidy to

\footnotetext{
${ }^{42}$ The original loan agreements typically prohibited debt buybacks. Hence, to be legal, buybacks require waivers from creditors. In many cases waivers have been granted. In other cases debtors may have bought back debt surreptitiously, through third parties, for example. A reason for the original restrictions might have been a fear that the debtor would take actions to manipulate the price of its debt, and then buy it back at depressed prices. A similar logic lies behind the prohibition on insider trading.
} 
direct foreign investment or environmental protection, with the amount of the subsidy depending upon both the price of the debt and the exchange rate.

We focus here on the buyback component of these schemes. One question that has generated a great deal of controversy is the division of any gains from a buyback between a debtor and its creditors. Bulow and Rogoff (1988a), for example, argue that buybacks financed out of the debtor's own resources at market prices benefit creditors at the expense of the debtor. Whether this is the case or not turns out to depend on two key magnitudes: (1) the extent to which creditors can collect the maximum that the debtor is willing to pay rather than to impose penalties for nonpayment and (2) how much current spending on buybacks reduces resources available for future repayment. We parameterize these magnitudes as follows: (1) In the event that the debtor lacks the incentive to pay all that it owes, it pays the most that it is willing, thus avoiding the cost of default, with probability $\pi$, and pays nothing, suffering the penalty of default, with remaining probability. (2) Each dollar of debtor resources used for current buybacks reduces what's available for future repayment by $\lambda$ dollars.

Average vs. Marginal Debt

To analyze buybacks we need to consider the price at which buybacks occur. The price should reflect what creditors expect to get paid. In terms of the two-period model developed in the previous section, the total value of outstanding debt to creditors amounts to:

$$
V^{c}(D)=\pi \int_{0}^{D} H d F(H)+[1-F(D)] D \text {. }
$$

Given the absence of seniority, the market price $q$ should equal the value per unit, or the average value of debt to the creditor:

$$
q=\frac{V^{c}(D)}{D}=\pi \int_{0}^{D} \frac{H}{D} d F(H)+[1-F(D)]
$$

What does the debtor gain by reducing its debt by one unit? Its total expected repayment plus expected harm from the cost of default is:

$$
V^{D}(D)=\int_{0}^{D} H d F(H)+[1-F(D)] D
$$


Differentiating with respect to $D$ gives the marginal cost of debt to the debtor, which is just $[1-F(D)]$, just the probability of full repayment. Except in the extreme case in which partial repayment never occurs $(\pi=0$ ) the value to the debtor of reducing debt by one unit is strictly less than the market price of debt. Buying back a unit of debt lowers what the debtor is willing to pay the next period by $\lambda q$, and lowers its contractual obligations by one. The first magnitude constrains what the debtor pays with probability $F(D)$ and the second magnitude constrains what it pays with remaining probability. Hence the debtor's expected payments fall by $1-F(D)-F(D) \lambda q$. What matters to the debtor, then, is how this magnitude compares with what the borrower pays to buy back a unit of debt, or $q$.

If $\lambda=0$, meaning that the loss of resources for the current buyback does not reduce future willingness to pay, then the buyback is at the debtor's expense. At the other extreme, if $\lambda=1$, meaning that resources used now reduce what the debtor is willing to pay in the future dollar for dollar, then the debtor benefits from the buyback. What happens to the creditor depends on the likelihood of efficient renegotiation. If $\pi=1$, as Bulow and Rogoff (1988a) assume, then the benefits to the two parties sum to zero: If the debtor loses then the creditor benefits and vice versa. If $\pi<1$, however, then it is possible for both parties to benefit. A buyback, by reducing the possibility of default, reduces the likelihood that the debtor will experience the cost of default.

\section{Buybacks and the Price of Debt}

How does a buyback affect the price of debt? Differentiating the expression for the price with respect to a buyback in amount $B$, and evaluating the result at $B=0$, gives an expression with the sign of:

$$
q-1+F(D)-\pi \lambda F(D)+(1-\lambda)(1-\pi) F^{\prime}(D) D \text {. }
$$

How does this magnitude relate to the effect of the buyback on the creditor's and debtor's situation? This expression has the same sign as the effect of the buyback on the total resources captured by the creditor: If the price goes up after a buyback then creditors benefit from the buyback, while if it falls they lose. As we showed in the previous section, however, if there is some chance that the debtor will experience default 
penalties, then an improvement in the creditor's situation does not necessarily come at the expense of the debtor. Both could gain. ${ }^{43}$

Secondary Market Prices: Bolivian and Other Experiences

A buyback that received particular attention from academics was undertaken by Bolivia. Bulow and Rogoff (1988a) report that when the possibility of the buyback was first discussed in September 1986. Bolivia's private bank debt traded at 6 cents on the dollar, so that its nominal debt of $\$ 670$ million had a market value of just $\$ 40.2$ million. In March 1988 , with donated funds, Bolivia bought back $\$ 308$ million in nominal debt for $\$ 34$ million (at a price of around 11 cents on the dollar). After the buyback the price of the remaining $\$ 362$ million in debt outstanding remained at 11 cents on the dollar, so that it had a market value of $\$ 39.8$ million. Since the market value of the debt presumably affects what creditors hope to collect, an implication is that the buyback had no effect on what creditors expected Bolivia to pay subsequent to the buyback. In other words, the resources captured by the creditors in the buyback itself was pure gravy. ${ }^{44}$ Whether the banks' gain was Bolivia's loss depends on the extent to which a reduction in debt led to any efficiency gain. The likelihood that potential efficiency gains were worth the cost of the buyback has been hotly debated.

More recently, Dooley, Fernandez-Arias, and Kletzer (1994) have undertaken a more comprehensive econometric analysis of secondary market prices with a panel of 21 developing countries

\footnotetext{
${ }^{43} \mathrm{~A}$ number of papers provide scenarios in which debt buybacks could benefit a debtor. Costa-Cabral (1993) provides a very general model of debt buybacks which incorporates a domestic investment decision, showing that a buyback can lead to more investment. Goldberg and Spiegel (1992) show that buybacks can help a debtor country by eliminating its incentive to direct investment away from sectors whose output is subject to seizure by disgruntled creditors. Detragiache (1993b) shows that the fiscal burden imposed by future debt can make buybacks desirable. Acharya (1991) provides a model in which buybacks signal a willingness to undertake investments that will increase repayment in the future. To support this hypothesis he provides evidence that: (1) creditors are more likely to provide debt relief to countries with buyback programs; (2) buybacks lead to higher secondary market prices of debt; and (3) a country's willingness to engage in buybacks is correlated with other measures of its creditworthiness. ${ }^{44}$ Sachs (1988), however, argued why troubled banks might nonetheless oppose buybacks. They had been carrying debt on their books at face rather than at market value. Selling the loans at the market price would force them to write down the value of their assets, possibly forcing liquidation.
} 
during 1986-1992. They conclude that the dominant factor governing price movements was the international interest rate, rather than conditions or policies in the countries themselves. ${ }^{45}$

\subsection{Public Initiatives}

The argument that the private sector cannot restructure sovereign debt efficiently has led to proposals for government intervention. Kenen (1990) and Sachs (1990), among others, propose that a public institution buy up debt from private creditors and restructure it. The argument is that it would overcome the coordination problem facing private creditors discussed in Section 4.1.2. An issue is whether the institution would finance itself. Proponents argue that problem debtors are indeed on the downward sloping parts of their "debt Laffer curves." Hence a public institution, by consolidating and reducing debt, would collect more than private debtholders could expect to receive.

Another form of public involvement is through participation in negotiations between private creditors and sovereign debtors. Recently this has taken the form of what are called "Brady plans" in which private creditors are asked to refinance debt, usually given the choice between providing new loans at fixed rates or accepting "exit bonds" with reduced principal and interest. In exchange for refinancing, public lending institutions have provided a partial guarantee of what is refinanced. This procedure makes creditors who refinance under the plan effectively senior to those who do not. How much these schemes will ultimately cost the public depends upon the extent to which the guarantees are called upon. ${ }^{46}$

Most discussion of either type of public involvement has taken the existence of the outstanding loans as given. An issue, however, is the extent to which private lenders and borrowers anticipate the possibility of subsequent public involvement when the loans are made initially. Even though public

\footnotetext{
${ }^{45}$ Other contributions to the literature on secondary market prices are Dooley (1988), Claessens, van Wijnbergen, and Pennachi (1992), Cohen and Portes (1992), and Dooley and Stone (1993). ${ }^{46}$ Spiegel (1993b) models burden sharing between private and official lenders in the presence of deposit insurance. A reason to give banks a "menu" of options is to overcome the heterogeneity problem discussed in section 4.1.2. Weaker banks, for example, might prefer to provide new money rather than to accept exit bonds since these have a higher option value. Demirguc-Kunt, Diwan, and Spiegel (1993) find that this is exactly what happened in the Brazilian debt reduction deal of 1988. Claessens, Oks, and van Wijnbergen (1992) analyze the Mexican experience after its Brady deal.
} 
intervention may be optimal ex post, i.e., once loans have been made, its anticipation could lead creditors initially to lend more than is efficient, so that, ex ante, public involvement makes things worse.

Bulow and Rogoff (1988b) demonstrate this possibility in a model of trilateral debt renegotiation among a sovereign debtor, its private creditors, and official institutions. If the negotiations fail private creditors will seek legal remedies which benefit them but which harm the debtor and the world economy as a whole. To avoid a breakdown in the negotiations the official institutions provide a transfer to the debtor to help it repay its private creditors. The original loan contracts reflect anticipated public involvement down the road. ${ }^{47}$

\section{Conclusion}

As stated in the introduction, the literature on sovereign debt that we survey here was motivated by the wave of commercial bank lending to developing-country governments during the 1970s and 1980s. As international credit markets evolve, an outstanding research issue is to identify how alternative modes of finance could avoid the potential market failures that this work points to. One issue is the extent to which other forms of finance would add to the fiscal burden of the recipient country. ${ }^{48}$ Another is how alternative forms would allocate exogenous risks between debtors and creditors. ${ }^{49}$ Third, and most problematic, is the extent to which governments of borrowing countries would be committed to protecting

\footnotetext{
${ }^{47}$ Wells (1993) models how changes in IMF lending procedures can influence the incentive of private borrowers to restructure debt.

${ }^{48}$ For example, direct foreign investment and equity investment do not add directly to the tax obligations of the borrowing country government. Nevertheless, one lesson of the debt literature is that foreign investors may force a government to assume the obligations of its private nationals. The potential for multiplicity of equilibria and capital flight remain unless the government can credibly desist from serving as the implicit guarantor of foreign private investment of any form.

${ }^{49}$ On the face of it, debt finance leaves the country bearing the full burden of domestic shocks. As Grossman and van Huyck (1988) argue, however, the opportunity to renegotiate syndicated bank loans implicitly allows a country to "default excusably" when it faces especially adverse circumstances. The greater dispersion of creditors in the case of bond finance might suggest that bonds would allow for much less flexibility in resetting terms in response to bad outcomes. Nevertheless, Eichengreen and Portes (1989) claim that the terms of bond issues were often renegotiated when the borrowing country ran into trouble. Conditions in international credit markets pose another source of risk. Detragiache (1992) compares the risk-sharing properties of floating and fixed rate contracts. Worrall (1990) and Atkeson (1991) analyze the risk-sharing characeristics of sovereign debt contracts in general equilibrium settings.
} 
the interests of foreign investors under alternative regimes. ${ }^{50}$ A lesson of the debt literature is that the incentive for a sovereign government to honor external liabilities is subtle, and highly sensitive to the overall environment provided by the international financial system.

${ }^{50}$ While sovereign debt is subject to default risk, direct foreign investment and equity investment are subject to the risk not only of expropriation, but of other government actions, such as changes in tax laws and regulations, that shift profits away from investors. The literature on expropriation includes papers by Eaton and Gersovitz (1984) and Cole and English (1988). Claessens (1995) provides a set of papers analyzing emerging equity markets in developing countries. 


\section{REFERENCES}

Acharya, Sankarshan (1991), "Debt Buybacks Signal Sovereign Countries' Creditworthiness: Theory and Tests," Finance and Economics Discussion Series Paper No. 180, Board of Governors of the Federal Reserve System.

Armendariz de Aghion, Beatriz (1990), 'International Debt: An Explanation of the Commercial Banks' Lending Behavior after 1982," Journal of International Economics, 28.

Alexander, Lewis S. (1987), Three Essays on Sovereign Default and International Lending, Ph.D. Dissertation, Yale University.

Atkeson, Andrew (1991), "International Lending with Moral Hazard and Risk of Repudiation," Econometrica, 59: 1069-1090.

Bhattacharya, Sudipto and Enrica Detragiache (1993), "The Role of Multinational Institutions in the Market for Sovereign Debt," Innocenzo Gasparini Institute for Economic Research Working Paper No. 39.

Bulow, Jeremy and Kenneth Rogoff (1988a), "The Buy Back Boondoggle," Brookings Papers on Economic Activity, 2: 675-704.

Bulow, Jeremy and Kenneth Rogoff (1988b), "Multilateral Negotiations for Rescheduling Developing Country Debt," International Monetary Fund Staff Papers, 35: 644-657.

Bulow, Jeremy and Kenneth Rogoff (1989a), "A Constant Recontracting Model of Sovereign Debt," Journal of Political Economy, 97: 155-178.

Bulow, Jeremy and Kenneth Rogoff (1989b), "LDC Debt: Is to Forgive to Forget?" American Economic Review, 79: 43-50.

Bulow, Jeremy and Kenneth Rogoff (1990), "Cleaning up Third World Debt Without Getting Taken to the Cleaners," Journal of Economic Perspectives, 4:31-42.

Bulow, Jeremy and Kenneth Rogoff (1991), "Sovereign Debt Repurchases: No Cure for Overhang," Quarterly Journal of Economics, 427: 1219-1235.

Chang, Roberto (1991), "Private Investment and Sovereign Debt Negotiations," C.V. Starr Research Report 91-47, New York University.

Claessens, Stijn (1995), "Symposium on Emerging Capital Markets," World Bank Economic Review, 9 Forthcoming.

Claessens, Stijn and Ishac Diwan (1990), "Investment Incentives: New Money, Debt Relief, and the Critical Role of Conditionality in the Debt Crisis," The World Bank Economic Review 4: 21-41.

Claessens, Stijn, Ishac Diwan, and Daniel Oks (1992), "Interest Rates, Growth, and External Debt: The Macroeconomic Impact of Mexico's Brady Deal," manuscript, The World Bank.

Claessens, Stijn, Daniel Oks, and Sweder van Wijnbergen (1993), "Interest Rates, Growth, and External Debt: The Macroeconomic Impact of Mexico's Brady Deal," manuscript, The World Bank. 
Claessens, Stijn, Sweder van Wijnbergen, and George Pennachi (1992), "Deriving Developing Country Repayment Capacity from the Market Prices of Sovereign Debt," World Bank Policy Research Paper No. WPS/1043.

Cohen, Daniel (1990), "Debt Relief: Implications of Secondary Market Discount and Debt Overhangs," The World Bank Economic Review 4: 43-53.

Cohen, Daniel (1991), Private Lending to Sovereign States: $A$ Theoretical Autopsy, Cambridge, MA: MTT Press.

Cohen, Daniel (1992), "The Debt Crisis: A Postmortem," NBER Macroeconomics Annual, 7: 65-105.

Cohen, Daniel (1993), "Low Investment and Large LDC Debt in the 1980s," American Economic Review, 83: 437-449.

Cohen, Daniel and Richard Portes (1990), "The Price of LDC Debt" CEPR Discussion paper No. 459.

Cohen, Daniel and Jeffrey Sachs (1986), "Growth and External Debt under Risk of Debt Repudiation," European Economic Review, 30: 579-560.

Cole, Harold and William B. English (1988), "Expropriation and Direct Investment," manuscript, International Economics Research Center, University of Pennsylvania.

Cole, Harold L. and Patrick J. Kehoe (1992), "Reputation Spillover Across Relationships with Enduring and Transient Benefits: Reviving Reputation Models of Debt," Federal Reserve Bank of Minneapolis Working Paper.

Cole, Harold L., James Dow, and William B. English (1995), "Defauit, Settlement and Signaling: Lending Resumption in a Reputation Model of Sovereign Debt," International Economic Review, 36.

Cooper, Richard N. and Jeffrey Sachs (1985), "Borrowing Abroad: The Debtor's Perspective," in Gordon W. Smith and John T. Cuddington, eds., International Debt and the Developing Countries. IBRD, Washington, D.C.

Corden, W. Max (1989), "Debt Relief and Adjustment Incentives: A Theoretical Exploration" in Jacob Frenkel, Michael Dooley, and Peter Wickham, eds., Analytical Issues in Debt. Washington, D.C., International Monetary Fund.

Costa-Cabral, Celia (1993), "Evaluating Debt Repurchases: What are the Alternatives to Investment?" Universidad Carlos III de Madrid Working Paper 93-43.

Demirguc-Kunt, Asli and Enrica Detragiache (1992), "Interest Rates, Official Lending, and the Debt Crisis: A Reassessment," Debt and International Finance Working Paper No. 932, the World Bank.

Demirguc-Kunt, Asli, Ishac Diwan, and Mark. M. Spiegel (1993), "Heterogeneity in Bank Valuation of LDC Debt: Evidence from the 1988 Brazilian Debt-Reduction Program," World Bank and New York University.

Demirguc-Kunt, Asli and Eduardo Fernandez-Arias (1992), "Burden Sharing Among Official and Private Creditors," World Bank Working Paper, 943.

Detragiache, Enrica (1992), "Optimal Loan Contracts and Floating-Rate Debt in International Lending to LDCs," European Economic Review, 36: 1241-1261. 
Detragiache, Enrica (1993a), "Sensible Buybacks of Sovereign Debt," Journal of Development Economics, forthcoming.

Detragiache, Enrica (1993b), "Fiscal Adjustment and Official Reserves in Sovereign Debt Negotiations," Johns Hopkins University.

Detragiache, Enrica and Paolo G. Garella (1993), "Debt Restructuring with Multiple Creditors: A Public Good Approach," Innocenzo Gesparini Institute for Economic Research Working Paper No. 47.

Diamond, Douglas (1984), "Financial Intermediation and Delegated Monitoring," Review of Economic Studies, 51: 393-414.

Diaz-Alejandro, Carlos F. (1984), "Latin American Debt: I Don't Think We Are in Kansas Anymore." Brookings Papers on Economic Activity, 2: 335-389.

Diaz-Alejandro, Carlos F. (1985), "Good-bye Financial Repression, Hello Financial Crash," Journal of Development Economics, 19: 1-24.

Diwan, Ishac and Stijn Claessens (1989), "Market Based Debt Reductions," in Husain and I. Diwan, eds., Dealing with the Debt Crisis.

Diwan, Ishac and Stijn Claessens (1989), "An Analysis of Debt-Reduction Schemes Initiated by Debtor Countries," Debt and International Finance Working Paper No, 153, World Bank.

Diwan, Ishac and Kenneth Kletzer (1992), "Voluntary Choices in Concerted Deals: The Menu Approach to Debt Reduction in Developing Countries," The World Bank Economic Review 6: 91-108.

Diwan, Ishac and Dani Rodrik (1992), "External Debt, Adjustment, and Burden Sharing: A Unified Framework," Princeton Studies in International Finance, 73.

Diwan, Ishac and Mark M. Spiegel (1993), "Are Buybacks Back?: Menu-Driven Debt Reduction Schemes with Heterogeneous Creditors," World Bank and New York University.

Dooley, Michael (1988), "Buybacks and the Market Valuation of External Debt," IMF Staff Papers 35: 215-229.

Dooley, Michael P., Eduardo Fernandez-Arias, and Kenneth M. Kletzer (1994), "Recent Private Capital Flows to Developing Countries: Is the Debt Crisis History?" NBER Working Paper No. 4792.

Dooley, Michael and Kenneth M. Kletzer (1994), "Capital Flight, External Debt, and Domestic Fiscal Policies," NBER Working Paper No. 4793.

Dooley, Michael and Mark Stone (1993), "Endogenous Creditor Seniority and External Debt Values," IMF Staff Papers, 40: 395-413.

Eaton, Jonathan (1987), "Public Debt Guarantees and Private Capital Flight," World Bank Economic Review, 7: 377-396.

Eaton, Jonathan (1990a), "Debt Relief and the International Enforcement of Loan Contracts," Journal of Economic Perspectives, 4:43-56.

Eaton, Jonathan (1990b), "Sovereign Debt, Reputation, and Credit Terms," NBER Working Paper No. 3424. 
Eaton, Jonathan and Mark Gersovitz (1981), "Debt with Potential Repudiation: Theoretical and Empirical Analysis," Review of Economic Studies, 48: 289-309.

Eaton, Jonathan and Mark Gersovitz (1984), "A Theory of Expropriation and Deviations from Perfect Capital Mobility," Economic Journal, 94: 16-40.

Eaton, Jonathan and Mark Gersovitz (1988), "Country Risk and the Organization of International Capital Transfer," in Jorge B. deMacedo and Ronald Findlay, editors, Debt Growth, and Stabilization: Essays in Memory of Carlos F. Diaz Alejandro. Oxford: Blackwell.

Eaton, Jonathan and Mark Gersovitz (1994), "Some Curious Properties of a Familiar Model of Debt and Default," forthcoming, Economics Letters.

Eaton, Jonathan , Mark Gersovitz, and Joseph Stiglitz (1986), "The Pure Theory of Country Risk," European Economic Review, 30: 481-513.

Edwards, Sebastian (1984), "LDC's Foreign Borrowing and Default Risk: An Empirical Investigation," American Economic Review, 74: 726-734.

Eichengreen, Barry and Richard Portes (1986), "Debt and Default in the 1930s: Causes and Consequences," European Economic Review, 30: 599-640.

Eichengreen, Barry and Richard Portes (1989), "Settling Defaults in the Era of Bond Finance," World Bank Economic Review, 3: 211-240.

Fernandez, Raquel and Jacob Glazer (1990), The Scope for Collusive Behavior among Debtor Countries," Journal of Development Economics, 32: 297-313.

Fernandez, Raquel and David Kaaret (1992), "Bank Heterogeneity, Reputation, and Debt Renegotiation," International Economic Review, 33: 61-78.

Fernandez, Raquel and Sule Ozler (1991), "Debt Concentration and Secondary Market Prices: A Theoretical and Empirical Analysis," NBER Working Paper 3654.

Fernandez, Raquel and Robert Rosenthal (1990), "Sovereign Debt Renegotiations: A Strategic Analysis," Review of Economic Studies.

Froot, Kenneth (1989), "Buy-Backs, Exit-Bonds, and the Optimality of Debt and Liquidity Relief," International Economic Review, 30: 45-70.

Gale, Douglas and Martin Hellwig (1989), "Repudiation and Renegotiation: The Case of Sovereign Debt," International Economic Review, 30: 3-31.

Gersovitz, Mark (1983), "Trade, Capital Mobility and Sovereign Immunity, "Research Program in Development Studies Paper No. 108, Princeton University.

Goldberg, Linda and Mark M. Spiegel (1992), "Debt Write Downs and Debt-Equity Swaps in s TwoSector Model," Journal of International Economics, 33: 267-283.

Grossman, Herschel I. and John B. van Huyck (1988), "Sovereign Debt as a Contingent Claim: Excusable Default, Repudiation and Reputation," American Economic Review, 78: 1088-1097.

Hellwig, Martin (1977), "A Model of Borrowing and Lending with Bankruptcy," Econometrica, 45: 1879-1906. 
Helpman, Elhanan (1989), "Voluntary Debt Reduction," International Monetary Fund Staff Papers, 36: $580-611$.

Helpman, Elhanan (1990), "The Simple Analytics of Debt Equity Swaps," American Economic Review, 79: $440-451$.

Jaffee, Dwight and Franco Modigliani (1969), "A Theory of Credit Rationing," American Economic Review.

Kahn, Robert B. (1984), "External Borrowing and the Commons Nature of Foreign Exchange," unpublished manuscript, Board of Governors of the Federal Reserve System.

Kaletsky, Anatole (1985), The Costs of Default. Twentieth Century Fund. New York: Priority Press.

Kaneko, Mamoru and Jacek Prokop (1993), "A Game-Theoretic to the International Debt Overhang," Journal of Economics, 1: 1-24.

Kenen, Peter (1990), "Organizing Debt Relief: The Need for a New Institution," Journal of Economic Perspectives, 4. 7-18.

Keynes, John Maynard (1924), "Foreign Investment and National Advantage," The Nation and Atheneum, 584-587.

Kletzer, Kenneth M. (1984), "Asymmetries of Information and LDC Borrowing with Sovereign Risk," Economic Journal, 94: 287-307.

Kletzer, Kenneth M. and Brian Wright (1990), "Sovereign Debt Renegotiations in a ConsumptionSmoothing Model," University of California at Santa Cruz.

Kreps, David M. and Robert Wilson (1982), "Reputation and Imperfect Information," Journal of Economic Theory, 27: 253-279.

Krugman, Paul (1988), "Financing vs. Forgiving a Debt Overhang: Some Analytic Notes," Journal of Development Economics, 29: 253-268.

Lindert, Peter and Paul Morton (1989), "How Sovereign Debt has Worked," in Jeffrey Sachs, editor, Developing Country Debt and Economic Performance. Chicago: University of Chicago Press.

Manuelli, Rodolfo (1986), "A General Equilibrium Model of International Credit Markets," Manuscript, Stanford University.

Milgrom, Paul and John Roberts (1982), "Predation, Reputation, and Entry Deterrence," Journal of Economic Theory, 27: 280-312.

Ozler, Sule (1989), "On the Relation Between Reschedulings and Bank Value," American Economic Review, 79: 1117-1135.

Ozler, Sule (1991), "Evolution of Commercial Credit Terms: An Empirical Study of Commercial Bank Lending to Developing Countries," Journal of Development Economics, 38: 79-97.

Ozler, Sule (1993), "Have Commercial Banks Ignored History?" American Economic Review 83: 608-620. 
Rosenthal, Robert (1991), "On the Incentives Assocaited with Foreign Debt," Journal of International Economics, 30: 167-176.

Rubinstein, Ariel (1982), "Perfect Equilibrium in a Bargaining Model," Econometrica, 50: 97-109.

Sachs, Jeffrey (1984), Theoretical Issues in International Borrowing. Princeton Studies in International Finance No. 54.

Sachs, Jeffrey (1988), "The Debt Overhang of Developing Countries," in Jorge B. deMacedo and Ronald Findlay, editors, Debt Growth, and Stabilization: Essays in Memory of Carlos F. Diaz Alejandro. Oxford: Blackwell.

Sachs, Jeffrey (1990), "A Strategy for Efficient Debt Reuction," Journal of Economic Perspectives, 4: 19 29.

Sachs, Jeffrey and Daniel Cohen (1985), "LDC Borrowing with Default Risk," Kredit und Kapital, 8: 211-235.

Spiegel, Mark M. (1992), "Concerted Lending: Did Large Banks Bear the Burden?" Journal of Money, Credit, and Banking, 24: 465-481.

Spiegel, Mark M. (1993a), "Fixed Premium Deposit Insurance and Collective Action Problems Among Banks," New York University.

Spiegel, Mark M. (1993b), "Burden-Sharing in Sovereign Debt Renegotiations," New York University.

Stiglitz, Joseph E. and Andrew Weiss (1981), "Credit Rationing in Markets with Imperfect Information," American Economic Review, 71: 393-410.

Wells, Robin (1993), "Tolerance of Arrearages: How IMF Loan Policy can Effect Debt Reduction," American Economic Review, 71: 621-633.

World Bank (1993), World Debt Tables.

Worrall, Thomas (1990), "Debt with Potential Repudiation," European Economic Review, 34: 10991109. 